\title{
INTENTION, INTERPRETATION, AND STORIES
}

\author{
JANE B. BARON $\dagger$
}

INTRODUCTION

This is an essay, first of all, about storytelling in "private" law-wills law, to be specific. It is also an essay about the complex interrelation between "public" and "private" issues in law generally. While this relation has been explored many times in the past, ${ }^{1}$ it continues to warrant attention today. ${ }^{2}$ Recent scholarship has taken great interest in stories and storytelling in "public" law contexts. ${ }^{3}$ To take but two examples, "outsiders" 4 and poverty

$\dagger$ Professor of Law, Temple University School of Law. This project was supported in part by a Temple University School of Law summer research stipend, for which I am most grateful. For student research assistance I am indebted to Richard Bendit, Joseph Handelman, Anthony Martignetti, Mira Rabin, and Jerry Tanenbaum. I thank Gregory Alexander, Mary Louise Fellows, and Laura Little, who read various early drafts of this piece, and I thank especially Rick Greenstein, who read every draft. All errors are mine.

1. For an early critique of the public/private distinction, see Robert L. Hale, Bargaining, Duress, and Economic Liberty, 43 CoLUM. L. REv. 603 (1943). For more recent critiques, see Symposium on The Public/Private Distinction, 130 U. PA. L. REV. 1289 (1982).

2. Examples of recent work attentive to the nature and significance of efforts to distinguish public and private spheres include Ruth Gavison, Feminism and the Pub. lic/Private Distinction, 45 STAN. L. REV. 1 (1992); Joan C. Williams, Rorty, Radicalism, Romanticism: The Politics of the Gaze, 1992 WIS. L. REV. 131; and Steven L. Winter, Foreword: On Building Houses, 69 TEX. L. REv. 1595 (1991).

3. A recent symposium issue on "Legal Storytelling" published by the Michigan Law Review illustrates this phenomenon. Many of the essays focus specifically on constitutional law issues. See, e.g., Milner S. Ball, Stories of Origin and Constitutional Possibilities, 87 MicH. L. REV. 2280 (1989); David Luban, Difference Made Legal: The Court and Dr. King, 87 MrCH. L. REv. 2152 (1989); Mari J. Matsuda, Public Response to Racist Speech: Considering the Victim's Story, 87 Micr. L. REV. 2320 (1989); Patricia Williams, The Obliging Shell: An Informal Essay on Formal Equal Opportunity, 87 Mich. L. REV. 2128 (1989).

Interest in storytelling in the law has not been confined to "public" law contexts. For an overview of the literature, see Jane B. Baron, The Many Promises of Storytelling in Law, 23 RUTGERS L.J. 79 (1991) (book review).

4. For a defmition and explanation of this term, and of the concept of "outsider 
lawyers have argued that storytelling can be used as a strategy to increase the power of those whose real world problems and everyday experiences of oppression are denied by conventional doctrinal approaches.' These scholars, among others, have suggested that stories and storytelling have great potential power to disrupt and alter established, uncritical perceptions of what the world is or can become. ${ }^{6} \mathrm{By}$ this process, it has been asserted, stories can change how we understand and decide legal disputes. ${ }^{7}$ Yet, with few exceptions, ${ }^{8}$ little attention has been paid to the means by which stories will actually be made central to decisionmaking processes: How will stories be brought before decisionmaking bodies? How might decisionmakers be compelled to hear them? Examining storytelling in the "private" law context of wills gives some insight into these questions.

jurisprudence," see Matsuda, supra note 3, at 2323-26.

5. On the use of stories by outsiders, see, e.g., id. On the use of stories in poverty law contexts, see, e.g., Anthony V. Alfieri, Reconstructive Poverty Law Practice: Learning Lessons of Client Narrative, 100 YALE L.J. 2107 (1991); Christopher P. Gilkerson, Poverty Law Narratives: The Critical Practice and Theory of Receiving and Translating Client Stories, 43 HASTINGS L.J. 861 (1992).

6. See, e.g., Kathryn Abrams, Hearing the Call of Stories, 79 CAL. L. REV. 971, 1031 (1991) (arguing that experiential narratives can provide."a vantage point outside the legal system, from which one can glimpse its partiality or subordinating effects"); Richard Delgado, Storytelling for Oppositionists and Others: $A$ Plea for Narrative, 87 MICH L. REV. 2411, 2413 (1989) ("Stories, parables, chronicles, and narratives are powerful means for destroying mindset-the bundle of presuppositions, received wisdoms, and shared understandings agaimst a background of which legal and pohtical discourse takes place.") (footnote omitted).

7. See, e.g., David R. Papke, Preface, in NARRattve AND the Legal Discourse: A READER IN STORYTELling AND THE LAW 1, 4-5 (David R. Papke ed., 1991):

[A]n increased sensitivity to various narratives in the legal discourse encourages lawyers, legal scholars and citizens to conceptualize the law differently. . . . A greater sensitivity to narrative enables us to break free of assumptions that law is objectively created and applied .... We can more freely enjoy and participate in the ongoing process of re-creating the law.

8. In a pair of articles, Steven Winter has relied on cognitive theory to explain how stories are used to make sense of and to communicate human experience. See Steven $\mathrm{L}$. Winter, The Cognitive Dimension of the Agon Between Legal Power and Narrative Meaning, 87 MICH. L. REV. 2225 (1989) [hereinafter Winter, The Cognitive Dimension]; Steven L. Winter, Transcendental Nonsense, Metaphoric Reasoning, and the Cognitive Stakes for Law, 137 U. PA. L. REV. 1105 (1989).

Others have also relied on cognitive theory to describe, explain, or prescribe strategies that will be effective in persuading juries during trials. See, e.g., W. LANCE BENNETT \& MARTHA S. FELDMAN, RECONSTRUCIING REALITY IN THE COURTROOM (1981); Steven Lubet, The Trial as a Persuasive Story, 14 AM. J. TRIAL ADVOC. 77 (1990); Albert J. Moore, Trial by Schema: Cognitive Filters in the Courtroom, 37 UCLA L. REV. 273 (1989). 
I contend that wills ought to be, but are not, understood as stories. The obstacles to this understanding of wills derive from many of the same political contests-over the nature of knowledge and meaning, over the relation between the individual and the state-that have characterized debates over "public" law issues. ${ }^{9}$ I argue that if we cannot hear wills as stories, then we will not be able to use stories effectively in "public" contexts. Testators almost by definition own property. ${ }^{10}$ They are sufficiently familiar with the legal system to enlist it in their efforts to dispose of that property. Wills doctrine supports their efforts, at least at the rhetorical level. Now if in this favorable context the law is nonetheless unable or unwilling to reach beyond written words to seek the once living persons who generated them, then how likely is it to attend to the much less familiar voices, the much less conventional stories, of those who are situated "outside" the mainstream of American legal culture? My aim is to sound a sobering note.

This Essay began as an exploration of territory travelled by many before me: the problem of will interpretation and, in particular, the much-criticized "plain meaning rule."

9. On one level, this result should be no surprise. A major point of the critiques of the traditional legal distinction between public and private law is that the "private" sphere is not separate from, but rather is infused with and to some extent structured by, "public" law. See, e.g., Hale, supra note 1. I develop this point in the context of wills law in Section I(C). To the extent that the distinction between public and private law collapses, one would expect the same sets of problems to appear in both "spheres." See Clare Dalton, An Essay in the Deconstruction of Contract Doctrine, 94 YALE L.J. 997 (1985); Frances E. Olsen, The Family and the Market: A Study of Ideology and Legal Refom, 96 HARV. L. REV. 1497 (1983).

My references in the text to "public" law are not meant to reaffirm the public/private law distinction. In using the terms "public" and "private" law, I mean only to advert to the doctrinal categories that are associated by tradition (and not by any form of logical or other necessity) with those terms-constitutional doctrines with "public" law; property and contract doctrines with "private" law.

10. It is, however, possible to make a will for reasons unrelated to property. The Umiform Probate Code, for example, defines the term "will" to include "any testamentary instrument that merely . . nominates a guardian . . . . UNIF. PROB. CODE § 1-201(56), 8 U.L.A. 11 (West Supp. 1992).

11. See Jesse Dukeminier \& Stanley M. Johanson, Wills, TRusts, and Es. TATES 319 (4th ed. 1990) ("A plain meaning in a will cannot be disturbed."); see also 4 William J. Bowe \& DOUglas H. PARKer, PAGE ON THE LAW OF Wills $\& 32.11$, at 284 (rev. ed. 1961) [hereinafter PAGE ON WiLls] ("[W]lien the will is unambiguous, its language is conclusive and exclusive evidence of the testator's intent.") (footnote omitted). Professors Langbein and Waggoner have suggested that the common law "plain meaning rule" might better be called the "no-extrinsic-evidence rule." Joln $\mathrm{H}$. Langbein \& Lawrence W. Waggoner, Reformation of Wills on the Ground of Mistake: Change of 
it this terrain was not abstract. In a nightmarish six-week period in 1989, my father and my father-in-law both died, each leaving a will. My father had written his own will; he (quite logically) believed he knew what it said, and indeed had complained about its being "fair" in its provisions, but "not the will he really wanted to make. But ironically, the will contained terms that in probate proceedings might have been interpreted to provide dispositions quite different from those my father said he had made. My fatherin-law, on the other hand, had his will drafted by an attorney. No matter how many times I or the will's scrivener explained its provisions to him, he professed not to understand its terms. Again ironically, the will exactly expressed the dispositive objectives my father-in-law said he had sought.

These two wills and their stories vindicate a widely held intuition that the connection between the words of testamentary instruments and the intention that is supposed to animate them can be extremely probleinatic. The problem is clearly larger than wills law in particular. It implicates generally recognized concerns about the nature of and relations between thought and language. It implicates also concerns over power and interpretive authority-concerns often associated with constitutional and literary theory. Yet disputes about the primacy of "authorial intent" have a particular poignancy in the area of testamentary instruments, where the law's purported objective is to effectuate the will of the testator. If state power to interpret is nothing else than the power to impute meanings not intended by the testator himself, then wills law's purported division between "private" power to decide and "public" power to effectuate decisions cannot be sustained.

I develop my points in several steps. First, I explain how and why the connection between words and "intention" has come to be the central issue in traditional will interpretation doctrine. As part of this discussion, I critique some of the assumptions (about private intentions and public knowledge of them) underlying the

Direction in American Law?, 130 U. PA. L. REv. 521, 524-28 (1982).

I refer in the text to the "plain meaning rule" that traditionally governed will interpretation at common law, not to currently debated views of "plain meaning" in the context of statutory interpretation. See, e.g., William N. Eskridge, Jr., The New Textualism, 37 UCLA L. REV. 621 (1990); Jerry L. Mashaw, Textualism, Constitutionalism, and the Interpretation of Federal Statutes, 32 WM. \& MARY L. REV. 827 (1991); William T. Mayton, Law Among the Pleonasms: The Futility and Aconstitutionality of Legislative History in Statutory Interpretation, 41 EMORY L.J. 113 (1992). 
conventional model of will interpretation. Next, I offer an alternative understanding of the process of reading and writing wills-one that relies on the model of storytelling. Finally, I assess why I suspect that this alternative understanding will not be widely accepted and why this skepticism might extend to the larger claims currently being made about the transformative potential of storytelling.

\section{ThE DILEMMA of "INDIVIDUAL" INTENT}

The rhetoric of wills law portrays wills as exercises of autonomy and self-determination. ${ }^{12}$ As a leading casebook puts it, "[w]ith few exceptions, ... [ [the law of donative transfers] rests on one basic premise: In a capitalistic economy based on the institution of private property owners have the widest possible latitude in disposing of their property in accordance with their own wishes whether they be wise or foolish." ${ }^{13}$ The state's involvement with these wishes is understood to be limited: "The statutes and cases in the field have as their purpose the discovery of the true intent of the property owner, not to thwart it, but to give it effect."14 The state's requirements with respect to wills should be those-and only those-that enable it to serve its supporting, implementing role.

The aspirations of the law of wills require the solution of two distinct problems: the problem of discovering the testator's wishes and the problem of neutrally implementing those wishes. The first is a problem of knowledge. The second is a problem of power. ${ }^{25}$ (1988)

12. Mary Louise Fellows, In Search of Donative Intent, 73 IowA L. REv. 611, 611-12

Wills law is not the only set of doctrines applicable to transfers effective at death. Most people's post-death distribution of property is accomplished by a sometimes complicated amalgam of probate and non-probate devices. See John H. Langbein, The Nonprobate Revolution and the Future of the Law of Succession, 97 HARV. L. REV. 1108 (1984). The latest revision of the Uniform Probate Code seeks to unify and harmonize the rules governing wills and other transfers effective at death. See UNIF. PROB. CODE art. II, Prefatory Note, 8 U.L.A. $68-69$ (West Supp. 1992). Yet despite these very dramatic changes, the right of a property owner to control (within limits of public policy) the disposition of his property at death-whether by probate or non-probate transfer-has not been seriously questioned.

13. Elias Clark et al, Cases and materials on Gratuitous transfers 1 (3d ed. 1985).

14. Id.; see also Michael Hancher, Dead Letters: Wills and Poems, 60 TEX. L. REV. 507,514 (1982) (describing the metaphoric description of the testator's intent as the "polestar" that guides will interpretation).

15. Cf. Dalton, supra note 9 , at $999-1000$ (describing the problems of knowledge and 
The problem of knowledge is addressed, doctrinally, by requirements directed to the form of the will. If courts are to defer to a testator's wishes, then they must have some way of knowing what those wishes are. ${ }^{16}$ The formal requirements of will execution-the necessity of a writing and of an attestation, for example-are designed to satisfy this need. ${ }^{17}$ They function in general to produce reliable evidence of the testator's wishes. This approach to the knowledge problem also addresses in part the problem of power, for the testator who manifests his wishes in compliance with the Wills Act can be confident that those wishes will actually be carried out. ${ }^{18}$ The problem of power is also addressed, at the interpretive level, by doctrines focusing attention on the will's words. If the testator's wishes are evidenced by the will's words, then those words must be made determinative if the testator's wishes are to be effectuated. ${ }^{19}$

Unfortunately, as has long been recognized, the doctrines created to serve the testator's wishes have the potential to undercut them. Will execution requirements, designed to ensure that the state implements only those wishes that are well considered and reliably presented, may deny effect to wishes due to minor defects of form. ${ }^{20}$

power as "central issues in any human endeavor of our time and place"). As is developed infra Sections B-D, a categorical distinction between the two problems is difficult to sustain.

16. See, e.g., Association of Survivors of 7th Ga. Regiment v. Larner, 3 F.2d 201, 203 (D.C. Cir. 1925) ("The instrument speaks when the voice of the testator is stilled by death.").

17. The precise requirements are specified by statute and vary from state to state. I refer to the requirements, generically, as the "Wills Act."

18. On the functional justification for the formalities of the Wills Act, see Ashbel G. Gulliver \& Catherine J. Tilson, Classification of Gratuitous Transfers, 51 YALE L.J. 1 (1941); John H. Langbein, Substantial Compliance with the Wills Act, 88 HARV. L. REV. 489 (1975). For a critique of this justification, see Jane B. Baron, Gifts, Bargains, and Form, 64 IND. L.J. 155 (1989).

19. See, e.g., Connecticut Junior Republic v. Sharon Hosp., 448 A.2d 190, 195 (Conn. 1982) (" "TT]he evidence of the intent of the devisor should be derived froin the writing, signed by him and solemnly attested; otherwise, innumerable would be the cases, where evidence of mistake would be claimed and proved.') (quoting Comstock v. Hadlyme Ecclesiastical Soc'y, 8 Conn. 254, 265-66 (1830)); Dempsey v. Holsen (Estate of Rosta), 444 N.E.2d 704, 712 (IIl. App. Ct. 1982) ("The cardinal rule of will construction . . . is the ascertainment of a testator's intention from the will itself.").

20. See Gulliver \& Tilson, supra note 18 , at $1-5$. This possibility has been realized in enough cases to provoke a variety of proposals designed to reduce the number and consequence of the formalities associated with will execution. See, e.g., Langbein, supra note 
This problem recurs at the interpretive level. The notion that the testator's personal wishes must govern commits the courts to a search for the testator's subjective thoughts. But the formal requirements designed to promote the trustworthiness of expressions of intent largely limit the search to the objective words of the will. ${ }^{21}$ In the absence of a direct or inevitable correlation between subjective thoughts and objective words, there is a potential for conflict, in which either one or the other must prevail. The doctrinal structure of wills law thus has the potential to create a type of zero-sum game, in which either (private) intent will prevail over the (public) rules ostensibly designed to effectuate it, or the rules will prevail over intent. ${ }^{22}$

As I explain below, the problems of will interpretation have almost always been defined in terms of this potential for conflict between subjective thoughts and objective words, between private freedom and the use of state power to effectuate it. ${ }^{23}$ These prob-

18 (arguing for substantial compliance standard); James Lindgren, Abolishing the Attestation Requirement for Wills, 68 N.C. L. REV. 541 (1990) (arguing for elimination of witness requirements). The 1990 revision of Article II of the Uniform Probate Code both eliminates many formalities altogether and allows courts to excuse harmless errors in complying with those formalities that remain. See, e.g., UNIF. PROB. CODE $\S 2-503,8$ U.L.A. 111-12 (West Supp. 1992).

For statistics on the frequency with which wills are denied probate due to execution errors, see Jeffrey A. Schoenblum, Will Contests-An Empirical Study, 22 REAL PROP. PROB. \& TR. J. 607 (1987). For some reservations about Schoenblum's conclusions, see Baron, supra note 18 , at 159 n.7.

21. See Fellows, supra note 12 , at 631 ("The states' dilemma is reconciling the desire to discover and effectuate the property owner's intent with the necessity to remain faithful to the words used to communicate that intent.").

22. Courts are often explicitly aware of this potential:

[O]ur holding in this case may not be in accord with the actual intention of the testator-existing im his mind-but certainly it is in accord with long established law that the court's finding shall be based on the intention of the testator-as expressed by the language of the will.

Mills v. Wylie, 466 S.W.2d 937, 938 (Ark. 1971).

As Professors Langbein and Waggoner have pointed out, the zero-sum potential of will interpretation is reduced by technical rules that enable courts to correct mistakes in a variety of cases without expressly admitting that that is what they are doing. See Langbein \& Waggoner, supra note 11, at 522, 555. Some courts nonetheless are unable or unwilling to use these rules and continue woodenly to apply the "plain meaning rule." See, e.g., Knupp v. District of Columbia, 578 A.2d 702, $704-06$ (D.C. 1990); Lawrence J. Rogers Trust v. Rogers (Estate of Rogers), 473 N.W.2d 36, 39-40 (Iowa 1991); Meredith v. Meredith (Estate of Mereditli), 782 P.2d 1313, 1315 (Nev. 1989). It is presunably because this sort of case arises with some frequency that the American Law Institute will soon consider a proposal to revise the Restatement of Donative Transfers to permit reformation of mistakes in wills.

23. Even the most innovative of recent scholarly proposals on will interpretation take 
lems arise in part because the interpretive doctrines envision the testator's "true" intentions as fundamentally inaccessible to others. Thus, the task of interpretation is focused not on discovering the testator's wishes, but rather on decoding his words-a different inquiry.

The doctrinal obsession with the will's words is not an effective solution to either the problem of knowledge or the problem of power. It is based on oversimplified and inaccurate presuppositions about the connections between thought and language and between the individual and the world of others. Wills law reflects a distinctly "modernist" consciousness that causes it to embrace an impoverished, lifeless view of the "freedom" it purports to advance. In this view, freedom consists wholly of choices, and the only choices that count are choices of words.

\section{A. The Role of Subjective Intent in Will Interpretation}

Most discussions of will interpretation begin with the proposition that, unlike a contract or a statute, a will is "unilateral" in nature. "The instrument purports to set forth the ideas and desires of one person." 25 The task of interpretation would seem to

the connection between words and particular thoughts to be the central issue, though they view the connection very differently. Professors Langbein and Waggoner would freely allow reformation of wills' words to reflect particular intentions established by clear and convincing evidence; their principal argument against the existing no-refornation rule is that it denies effect to proven thoughts in deference to written words without serving any legitimate state concerns for evidentiary reliability or Wills Act compliance. See Langbein \& Waggoner, supra note 11 , at 528-29.

In contrast to Professors Langbein and Waggoner, Professor Fellows would abandon the attempt to discover the testator's subjective wishes and would instead openly impute intentions reflective of competent estate planning techniques and a preference for family. Fellows, supra note 12, at 613. Yet Professor Fellows's proposal is animated by skepticism about the possibility of drawing any accurate connection between the testator's thoughts and the words used to express them. Id. at 631-34.

Both of these excellent and quite different proposals are responses to the problem of the connection between subjective thoughts and the words purporting to convey them, the nature of the connection between subjective intent and objective manifestations.

24. See, e.g., 9 JOHN H. WIGMORE, EvidENCE IN TRIALS AT COMMON LAW $\S 2467$, at 231 (James H. Chadbourn rev. ed., 1981); Edinond N. Cahn, Testamentary Construction: The Psychological Approach, 26 GEO. L.J. 17, 17-18 (1937); Fellows, supra note 12, at 611 ; see also Hancher, supra note 14, at 510 ("The trouble with the interpretation of statutes or of constitutions is the same as the trouble with the interpretation of folk songs: too many folks spoil (overcomplicate) the concept of 'the author.' It is easier to think about a single author, a single testator.").

25. Richard R. Powell, Construction of Written Instruments, 14 IND. L.J. 199, 207 
follow directly from this understanding of what a will is. "Some one has spoken and we must now envisage what was in the mind of that one when he spoke." ${ }^{26}$ The "ultimate goal" is to ascertain the testator's "actual desires."

This notion of the goal of will interpretation is entirely consistent with the view that a will expresses an individual's free choices-and thus is conceptually appealing. In practice, however, a testator's thoughts cannot be directly discovered because individual human will is a "formless substance." "The intent of the writer, the ideas existing in his mind, cannot be known to us with certainty: we can only ascertain them to a greater or lesser degree of probability from outward marks or signs."20 Chief among these outward marks are the words employed by the writer, but other marks may exist. ${ }^{30}$ If the testator's actual thoughts cannot be ascertained directly, then the goal of interpretation must be redefined to some degree. The goal becomes to infer from external marks the internal thoughts they reflect and embody. ${ }^{31}$ In pursuit of this goal, words and other external signs are used strategically, as means to an end:

Every written instrument is the attempted recordation of a series of ideas theretofore had by some definite individual .... Obviously the first task, then, is to squeeze out from each of these segregated paragraphs, sentences, phrases or words, just as near

(1939).

26. Id. at 208.

27. Id.; see also 4 PAGE ON WiLts, supra note 11, $\$ 30.1$, at 2 ("The primary purpose in construing a will is to determine the very disposition which the testator wanted to make, to determine if possible his actual intent ....").

28. Cahn, supra note 24, at 17; see also Kevin L. Keeler, Comment, Direct Evidence of State of Mind: A Philosophical Analysis of How Facts in Evidence Support Conclusions Regarding Mental State, 1985 WIS. L. REV. 435, 435-36 (noting that the law of evidence supposes that "proof of state of mind is never direct, because . . thoughts . . . are not directly observable by anyone except the person who experiences them").

29. Francis Vaughan Hawkins, On the Principles of Legal Interpretation, with Reference Especially to the Interpretation of Wills, in JAMES B. THAYER, A PRELIMINARY TREATISE ON EVIDENCE AT THE COMMON LAW 577, 580 (Boston, Little, Brown \& Co. 1898); see also Fellows, supra note 12, at 611-12 ("The state . . . has no direct access to the property owner's subjective will. It can only determine the manifestation of the property owner's will through words and actions.") (footnote omitted).

30. Hawkins, supra note 29 , at 580 .

31. 9 WIGMORE, supra note $24, \S 2404$, at 11; Powell, supra note 25 , at 201; see Hawkins, supra note 29, at 580-81; Oliver W. Holmes, The Theory of Legal Interpretation, 12 HARv. L. REv. 417, 419 (1899). 
an approximation to the idea sought to be embodied therein, as is obtainable. ${ }^{32}$

Unfortunately, the strategy is imperfect. The least problematic, most easily accessible set of signs--words-is not a perfect code of signals. ${ }^{33}$ Even if words were a perfect code, there would be no guarantee that writers would use the code with perfect accuracy. ${ }^{34}$ Complicating matters further is the fact that the words of the will may not have been chosen by the testator, whose ideas are ostensibly at issue, but by the testator's attorney. ${ }^{35}$ The possibility of a lack of exact congruence between external words and internal thoughts is troubling. It reduces the reliability of the inferences about intent that can be drawn from the words of the will. ${ }^{36}$ The Wills Act's requirement of formally executed words does not, alone, provide all the evidence (signs) needed to solve the problem of knowledge.

The obvious solution would be to supplement the evidence contained in the will with other evidence bearing on the testator's

32. Powell, supra note 25, at 201; see also Howard W. Elphinstone, On the Interpretation of Formal Documents, in 3 JURID. SOC. PAPERS 251, 251 (1871) ("Man communicates his thoughts and wishes by means of physical signs addressed to the senses. The solution of the problem of interpretation consists in discovering from the signs made use of, the thoughts and wishes intended to be expressed ....").

33. Zechariah Chafee, Jr., The Disorderly Conduct of Words, 41 Colum. L. REv. 381, 386 (1941); Hawkins, supra note 29, at 584-85; Holmes, supra note 31, at 417. For contemporary treatments of the notion of language as a code of word-signals, see J.M. Balkm, Deconstructive Practice and Legal Theory, 96 YALE L.J. 743 (1987); Gary Peller, The Metaphysics of American Law, 73 CAL. L. REV. 1151 (1985); and Joan C. Williams, Critical Legal Studies: The Death of Transcendence and the Rise of the New Langdells, 62 N.Y.U. L. REV. 429 (1987).

34. Hawkins, supra note 29 , at 584-85.

35. Fellows, supra note 12, at 633; Langbein \& Waggoner, supra note 11, at 581; Powell, supra note 25 , at 208-09.

For a recent example of this phenomenon, see Redenius v. Redenius (Estate of Redenius), 455 N.W.2d 295, 299 (Iowa Ct. App. 1990) (estate tax marital deduction clause included in a will, contrary to the testator's intent, because the attorney "routinely" included such clauses in the wills he prepared for inarried couples).

The role of the attorney in creating as well as recording the testator's intentions is explored further infra in the text accompanying notes 62-70 and 78-79.

36. See Fellows, supra note 12, at 612 ("The state's dependence on the property owner's manifestation of intent moves its inquiry from identifying subjective intent to imputing intent.") (footnote omitted); Powell, supra note 25, at 208-09 ("The presence of this word-man between the brain of the conveyor and the symbols presented for construction makes it necessary sometimes to query the accuracy of the instrument as a recordation of the mind of the conveyor."). 
subjective thoughts, to look to other external "marks or signs" of those thoughts. Such a step, however, immediately implicates problems of power. The will's words, produced in compliance with the Wills Act, have at the least been authenticated by the testator. However problematic their connection to the testator's "formless" thoughts, the argument goes, signs external to the will are presumptively even less reliable. ${ }^{37}$ Resort to such signs runs several risks. At worst, the wishes of others will control the disposition of the testator's property. ${ }^{38}$ Even if that does not occur, legal recognition of signs external to the will jeopardizes the achievement of legal objectives ancillary to intent-effectuation, such as promoting compliance with the Wills Act and enhancing the stability of legal language. ${ }^{39}$

At this step in the analysis, the commentators appear to differ in their conceptions of the precise relation between words, intentions, and evidentiary rules. But the differences are only apparent. All agree that if words had single meanings and usages which testators could effectively be forced to use, the knowledge, power, and ancillary issues could be harmoniously resolved: Testators would express their wishes by writing them down, readers would discover those wishes by reading the wills' written words, and language would be used and read consistently over time. However, the hope that words have unproblematic single meanings and usages is universally regarded as utopian..$^{40}$ In the absence of a direct

37. See, e.g., Connecticut Junior Republic v. Sharon Hosp., 448 A.2d 190, 197 (Conn. 1982) (expressing concern that admission of extrinsic evidence would do away with part of the protection of the Statute of Frauds and leave every will open to interpretation "on a claim of a different intent").

38. See, e.g., Charles A. Graves, Extrinsic Evidence in Respect to Written Instruments, 28 AM. L. REv. 321, 326 (1894) ("[T] he court must interpret the will of the testator, not nake his will for him . ...").

39. Richard W. Power, Wills: A Primer of Interpretation and Construction, 51 IOWA L. REV. 75, 105-06 (1965).

In light of the ritual, evidentiary, protective, and channelling functions said to be served by Wills Act formalities, see supra text accompanying notes 17-18, the objective of promoting Wills Act compliance is not unrelated to the goal of effectuating intent. Similarly, the more consistent the meaning accorded legal language, the more confidently such language can be used to express testamentary wishes. Thus, there is no necessary conflict between these ancillary objectives and the goal of carrying out the testator's actual wishes. Indeed, it is possible to see them as means toward achieving the intenteffectuation goal.

40. See THAYER, supra note 29, at 428-29; Charles P. Curtis, A Better Theory of Legal Interpretation, 3 VAND. L. REV. 407,409 (1950); Holmes, supra note 31, at 417. 
or inevitable connection between words and the wishes animating them, it would seem logical to argue that interpretation should focus on the wishes. Yet, despite their apparently vehement disagreement over interpretive issues, the commentators are surprisingly uniform in their insistence that interpretation must focus on the words. There is widespread agreement that although the Wills Act empowers testators to express their "formless" wishes in a manner the law will recognize, it limits their power to express their wishes by manifestations external to the written will. As one commentator put it: "The will, a unilateral act, has no existence apart from the writing which the testator executes. He is the only person whose intention is relevant, and his intention is relevant only to the extent it finds expression in the will.",

The task of finding the "expressed" intention can be approached in a number of quite divergent ways. For example, the focus might be on the meaning a will's words might have "in the mouth of a normal speaker of English," ings of the words, ${ }^{43}$ or on the particular meaning the words might have to a particular testator. ${ }^{44}$ These divergent approaches to the formulation of the task are accompanied by similarly divergent approaches to the question of the nature and extent of extrimsic evidence that can be admitted in will interpretation cases. ${ }^{45}$

41. Power, supra note 39 , at 105 . Some commentators have seen this idea as flowing directly from the writing requirement of the Statute of Frauds and the Statute of Wills. See, e.g., 4 PAGE ON WILLS, supra note 11, \& 30.7, at 38-39; JAMES WIGRAM, AN EXAMINATION OF THE RULES OF LAW RESPECTING THE ADMISSION OF EXTRINSIC EVIDENCE IN AID OF THE INTERPRETATION OF WILLS 1 (London, A. Maxwell, 3d ed. 1840). Others have seen the policy as relating to the protection of the integrity of integrated documents. See, e.g., 9 WIGMORE, supra note 24, § 2471, at 239.

42. Holmes, supra note 31 , at 417.

43. Power, supra note 39, at 103-04.

44. See Graves, supra note 38 , at 323 ("[T]he true object of legal interpretation [is] [n]ot the meaning of the words alone, nor the meaning of the writer alone, but the meaning of the words as used by the writer.").

The divergent views, almost comical in the fineness of the distinctions on which they rely, are summarized and contrasted in Albert M. Kales, Considerations Preliminary to the Practice of the Art of Interpreting Writings-More Especially Wills, 28 YALE L.J. 33 (1918), and Sidney L. Phipson, Extrinsic Evidence in Aid of Interpretation, 20 L.Q. REV. 245 (1904).

45. For a summary of approaches, see Phipson, supra note 44 , at $254-71$. For a survey of cases which also exhibit a variety of approaches, see 4 PAGE ON WILLS, supra note 11 , ch. 32 . 
Yet despite these disagreements and the vehement disputes among those purporting to propose or oppose any variety of "plain meaning rule," there is widespread agreement on the proposition that the inquiry in will interpretation cases involves the meaning - ordinary, legal, or individual - of the testator's words, and that interpretation cannot be concerned with thoughts that are in no way reflected in the words of the will. ${ }^{46}$ Wigmore's statement is typical:

Interpretation . . . is concerned with the sense of the word used and not with the will to use that particular word .... If [a person] has exercised a volition to utter something, then he is responsible for such utterance as is in external appearance the utterance he intended-whether or not he actually intended it. On the other hand, the sense of his word as thus uttered-his fixed association between that symbol and some external object-may usually be given full effect if it can be ascertained. ${ }^{47}$

That is to say, interpretation does not seek to discover the actual wishes in the testator's mind, but rather seeks the meaning of the testator's words-and may attend to the testator's personalized or idiosyncratic uses of language. Reformulated in this way, the goal of will interpretation is no longer to discover and implement the testator's actual wishes, but rather to decode the testator's words and give effect to-i.e., follow-them. ${ }^{48}$

46. See, e.g., 4 PAGE ON WILls, supra note 11, 830.7 , at 44 ("The question always before the mind of the court is not what should testator have meant to do or what words would have been better for testator to use, but what is the reasonable meaning of the words which he has actually used.") (footnote omitted).

On this point, there is striking agreement among those who see themselves as antagonists. Although Hawkins found much to criticize in Wigran's treatise, his own takes a remarkably sinilar position on this issue. Compare FranCIS VAUGHAN Hawkins, A CONCISE TREATISE ON THE CONSTRUCTION OF Wills 1 (1885) ("In construing a will, the object of the Courts is to ascertain, not the intention simply, but the expressed intentions of the testator, i.e. . . . the meaning of the words . ...") with WiGRAM, supra note 41, at 3 ("[T]he question in expounding a will is not-What the testator meant? as distinguished from-What his words express? but simply-What is the meaning of his words?") (footnote omitted).

47. 9 W1GMORE, supra note $24, \S 2459$, at 188; see also Boatınen's Union Nat'l Bank v. Welton, 640 S.W.2d 497, 502 (Mo. Ct. App. 1982) (extrinsic evidence "[i]s not admissible to show [the testator] meant one thing when he said another or to show an intention not expressed in the will ..., or to aid in making an intended instrument which was not in fact made"); WIGRAM, supra note 41, at 3 ("[A]ny evidence is admissible, which, in its nature and effect, simply explains what the testator has written; but no evidence can be admissible which, in its nature or effect, is applicable to the purpose of shewing merely what he intended to have written.").

48. See, e.g., In re Estate of Nagl, 408 N.W.2d 768, 771 (Iowa Ct. App. 1987) ("We 
The reformulation of the goal of interpretation as the discovery of the meaning of words does not necessarily imply a rejection of intent-effectuation as an ideal. Some abandon the search for actual thoughts only because of the practical difficulty of finding them. ${ }^{49}$ Others see words, despite their imperfection as a code, as functioning acceptably well as signs of actual intent. ${ }^{50}$ Still others see the focus on words as a limitation necessitated by the doctrines requiring a will to be in writing ${ }^{51}$-doctrines which are themselves capable of effectuating and protecting private intentions. ${ }^{52}$ Yet despite a diversity of views as to the reason, there is remarkable agreement about the result: Interpretation's goal is to discover the meaning not of the testator's will, but of the will's words. Put another way, the testator's "intent" is really only relevant to the extent that he chose to use particular words. As the following sections illustrate, this can be a very anemic form of effectuating the testator's wishes.

\section{B. The Meaning of Words and the Problem of Knowledge}

The intention to use a particular word, or to denote one particular thing or person (e.g., "wife") when one employs a given word (e.g., "Mother"), are but two of many intentions a testator might have in making a will. One can easily imagine other inten-

consider not what the testator meant to say but what he meant by what he did say."); In re Gustafson, 547 N.E.2d 1152, 1153-54 (N.Y. 1989) ("Courts construing donative imstruments are governed by a threshold axiom: a testator's intent, as ascertained 'from the words used in the will' . . . reigns supreme.") (emphasis added); Gehl v. Reingruber (In $r e$ Estate of Gehl), 159 N.W.2d 72, 75 (Wis, 1968) ("The essence of our inquiry then is to determine the reasonable meaning of the words actually used.").

49. Chafee, supra note 33, at 401-02; Curtis, supra note 40, at 409; Fellows, supra note 12 , at 612 .

50. Graves, supra note 38, at 326; Hawkins, supra note. 29, at 590; Powell, supra note 25, at 234; see also Hebden v. Keim, 75 A.2d 126, 129 (Md. 1950) ("[T]he Court, in construing a will, is governed, not by what the Court may think the testator wanted to say, but by what his words actually meant, because his words were designed to express his intention.").

51. See, e.g., Hawkins, supra note 29 , at 602 ("A . . . will . . . is unade with the knowledge of the command of the law, which requires the writer to express himself fully and completely, and gives validity to the instrument only on the condition of reasonable compliance with the demand which it has imposed."); Kales, supra note 44, at 33-34 (stating that the common law "has unequivocally made the writing the legal act which is enforced, and in consequence it is the writing alone which constitutes the subject inatter to be interpreted").

52. See supra note 39. 
tions that might bear on the terms of a will, such as the intent to achieve certain overall dispositive objectives, the intent to "do the right thing," or the intent to reward an individual to whom the testator feels grateful..$^{53}$ Although wills law never overtly renounces intent-effectuation as a goal in the ideal sense, intentions of the latter sort become immaterial in the technical sense once interpretation is limited to an inquiry into the meanings of words. ${ }^{54}$ As Thayer long ago pointed out, the definition of the goal of interpretation operates as a rule of substantive law:

In so far as a thing is forbidden to construction, of course there is no use in trying to give evidence in support of it: the fullest extrinsic evidence, the most convincing and regular aggregation of extrinsic facts, if offered to support an inadmissible contention, is itself inadmissible; but it is so because the contention itself is out of place. ${ }^{35}$

To the extent that the issue in interpretation proceedings involves the testator's words, as opposed to his actual wishes, evidence concerning the latter serves no purpose. ${ }^{56}$

This rule has clear practical deficiencies as a solution to the problem of knowledge. ${ }^{57}$ To the extent that it renders certain in-

53. See Hancher, supra note 14 , at 522 (contrasting the intention to write certain words, the intention to cause annoyance by those words, and the intention "that one's words be understood as enacting one ineaning rather than another").

54. See MCCORMICK ON EVIDENCE 541. (Edward W. Cleary ed., 3d ed. 1984) (materiality looks to the relationship between propositions for which evidence is offered and the issues in the case; what is "in issue" is controlled in part by substantive law); M.C. Slough, Relevancy Unraveled, 5 U. KAN. L. REV. 1, 5 (1956) ("Though an evidential fact be relevant under the rules of logic, it is not material unless it has a legitimate and effective bearing on the decision of the ultimate facts in issue.").

55. THAYER, supra note 29, at 448; see also Kales, supra note 44 , at 43 ("The rule which excludes objects and purposes of the inducement [to the writing of the will] as a subject matter of interpretation . . . is a rule of the substantive law of interpretation.").

56. See LAWRENCE W. WAGgoner ET Al., FAMILY PROPERTY LAW 546 (1991) ("If equity will not entertain suits to reform wills, no purpose would be served by allowing the introduction of extrinsic evidence to contradict clear and unambiguous terms in a will.").

57. Some of these difficulties can be overcome-and extrinsic evidence admitted-using established exceptions to and qualifications of the "plain meaning rule." For example, extrinsic evidence is almost always admissible to identify the subject or object of a devise. See, e.g., American Cancer Soc'y v. Sutton (Estate of Kremlick), 331 N.W.2d 228 (Mich. 1983). Extrinsic evidence is also admissible to explain "anbiguities." See, e.g., Redenius v. Redenius (Estate of Redenius), 455 N.W.2d 295 (Iowa Ct. App. 1990); Mell v. Page (Estate of Mell), 716 P.2d 836 (Wash. 1986). Such evidence is also admissible to show the circumstances surrounding the testator at the time the will was executed. See, 
tentions legally irrelevant, some parts or aspects of the testator's actual wishes will not be investigated at all..$^{58}$ Thus, "[i]n countless cases of palpable mistake, the courts have felt obliged to enforce the Wills Act literally even though it is manifest that to do so defeats the basic goal of the Wills Act, which is to implement the testator's intent." "s9

In addition to this problem of omission, there is the previously mentioned problem that the actual words of a will are likely to be those of an attorney. "[C]ommonly, the language of a will is the testator's only by adoption; he forms an intention that he communicates to his lawyer, and he relies upon the lawyer to draft the appropriate language." $\mathrm{My}$ father-in-law's will exemplifies this phenomenon. Although the will did in the end effectuate his announced objectives, my father-in-law could no more have explained the meaning of its highly technical words than he could explain the terminology used by nuclear physicists. Any search for the meaning he intended the will's words to have would be futile. As Professor Fellows has pointed out, this problem of "remoteness between property owners and the instruments purporting to reflect their donative intent" is encountered frequently in attorney-drafted instruments. ${ }^{61}$

The problem of remoteness further underscores the artificiality of the inquiries of will interpretation, once that process is reformulated as a quest for the meaning of words. A view to the meaning of words not chosen by the testator is at the least an indirect way to anything the testator thought. Yet to the extent that the attorney acts merely as scrivener, "translating" the testator's own clear-

e.g., Hembree v. Quinn (Estate of Russell), 444 P.2d 353 (Cal. 1968). However, evidence of the testator's oral declarations will usually be excluded. See, e.g., Estate of Utterback, 521 A.2d 1184 (Me. 1987). For a complete treatment of these qualifications and exceptions, see 4 PAGE ON WILLS, supra note 11, ch. 32.

58. Cf. Kim L. Scheppele, Foreword: Telling Stories, 87 MICH. L. REV. 2073, 2097 (1989) ("[S]tandards of legal relevance, appearing to limit the gathering of evidence neutrally to just 'what happened' at the time of 'the trouble,' may have the effect of excluding the key materials of . . . stories. And this apparently harmless legal habit has effects that are not at all harmless."); see also Walter O. Weyrauch, Law as Mask-Legal Ritual and Relevance, 66 CAL. L. REv. 699, 707 (1978) ("Both rules of evidence and conceptions of relevance act to exclude certain information, often of a human nature, that cannot be subsumed under a given rule, and therefore have elements of legal masks.").

59. Langbein \& Waggoner, supra note 11 , at 529.

60. Id. at 581 .

61. Fellows, supra note 12 , at 633. 
ly expressed ideas into legal phraseology and terms, it is merely indirect. The problems of omission and remoteness are problems of finding through the formal words of the will intentions that are assumed to have existed, albeit "formlessly," independent of the instrument itself.

More troubling, however, is the possibility that even ideas initiated by the testator are transformed in the process of being "translated" into legal terms. "If language is intimately bound up with the way we think about experience, then talking about experience in a different language necessarily entails knowing that experience in a somewhat different way." ${ }^{63}$ It would be comforting to believe that terms like "testator," "devisee," or "tangible personalty" are just fancy or technical equivalents of "person who makes a will," "person to whom property is left in a will," and "movable objects." Yet the legal vocabulary may be less particularized, personal, and accessible than "ordinary" words. ${ }^{64}$ Thus the legal terms may be regarded not as alternative ways of saying the same things, but rather as saying different things.

Similarly, the legal categories and classifications that an attorney applies to the client's problem may affect what facts "count." The process by which "facts" are changed in the encounter with an attorney has been described by one commentator as follows:

62. For example, one commentator has observed:

[T] he law can be seen ... as a way of talking about real events and actual people in the world. At its heart it is a way of telling a story about what has happened in the world ....

... [S]ince the story both begins and ends in ordinary language and experience, the heart of the law is the process of translation by which it must work, from ordinary language to legal language and back again.

JAMES B. WHTTE, HERACLES' BOW 36 (1985).

The role of the attorney in "influencing" the testator's wishes is explored further infra text accompanying notes 78-79.

63. Clark D. Cunningham, A Tale of Two Clients: Thinking About Law as Language, 87 MICH. L. REV. 2459, 2483 (1989).

64. See id. at 2491 ("Like more familiar forms of language, law creates knowledge by dividing up the spectrum of human experience into new basic categories. But this new knowledge, like all forms of knowledge, involves a loss, a reduction of the particularity of experience and the perspectives of other understandings.") (footnote omitted); Delgado, supra note 6, at 2428 (the linguistic code required by the court for a complaint may sterilize the facts and strip them of the features that gave them meaning for the person filing the complaint). 
The initial naive description by the [client] . . . activate[s] a set of legal categories in the lawyer's mind. The legal categories are tested against the raw description to find plausible fits . . . .

... The description of the facts of the case is constrained by the lawyer's view of the available courses of legal action .... The lawyer researches the legal doctrine pertaining to those categories that have been shown to be relevant in the first iteration .... The process of matching potentially relevant legal materials against the facts as described by the [client] results in highlighting certain facts, downplaying others, and omitting the irrelevant ones. ${ }^{65}$

The reconstruction of his ideas in terms of legal categories may cause the client to perceive the reconstructed version as removed from his life. ${ }^{66}$ The client who approaches an attorney about a will may do so because of a recent death in his family, ${ }^{67}$ but the enormous emotional significance of that event to the client may be completely irrelevant to the attorney in drafting the client's will. ${ }^{63}$ Professor Thomas Shaffer has suggested that effective testamentary counseling "is a matter of helping the client to accept, recognize and clarify ... negative feelings" about death, but "this critical beginning is evaded as long as possible and occurs very late in the typical will interview." "clients largely talk past their lawyers, and interpretive activity

65. KIM L. SCHEPPELE, LEGAL SECRETS 97-98 (1988) (footnotes omitted); see also Douglas W. Maynard, Narratives and Narrative Structure in Plea Bargaining, 22 LAW \& SOC'Y REV. 449, 475-76 (1988) (noting that in plea bargaining settings, "attorneys may scan the material available to them as a 'case' for its 'storyable' characteristics" in order to make choices about what will be most effective in supporting their respective bargaining positions).

66. SCHEPPELE, supra note 65 , at 104; see also William H. Simon, The Ideology of Advocacy: Procedural Justice and Professional Ethics, 1978 WIS. L. REV. 29, 114 (noting that a client's need to adopt the linited ends that the legal system imputes to him in order to be recognized by others may cause the "alienation of the individual from his ends").

67. MARVIn B. Sussman ET AL., The FAMILY AND INHERITANCE 204 (1970).

68. See id. at 215 ("Attorneys do not see themselves as psychologists or psychiatrists ... . They desire a normal business transaction."); see also Austin Sarat \& Wilham L.F. Felstiner, Law and Social Relations: Vocabularies of Motive in Lawyer/Client Interaction, 22 LAW \& SOC'Y REV. 737, 742 (1988) (In interviews concerning divorce cases, "[c]lients focus their interpretive energy in efforts to construct an explanation of the past and of their marriage's failure. Lawyers avoid responding to these interpretations because they do not consider ... [them] relevant to the legal task of dissolving it.").

69. Thomas L. ShafFer, Death, Property, AND Lawyers 97 (1970). 
proceeds without the generation and ratification of a shared understanding of reality." 70

The point is not that it is wrong for an attorney to use legal language, or to think about the testator's needs in terms of available legal categories and devices. The point is rather that these activities affect the testator's own perception and definition of his needs. The steps necessary to effectuating intent influence the formulation of intent.

At this level, the problems of will interpretation illustrate and exemplify a more general problem concerning the interrelation of thought and language. On the one hand, we use language as a vehicle to express thoughts. On the other hand, the conventions and rules of language constrain in some measure what it is possible for us to think. ${ }^{11}$ In light of this dilemma, it is somewhat misguided to define the goal of will interpretation, even in the ideal, as the discovery of the thoughts and wishes "behind" the words of the will.

\section{The Meaning of Words and the Problem of Power}

If the wishes said to be expressed in a will are to some degree a product of, rather than the source of, the words purporting to reflect or represent them, they are also in some measure a product of the public power which purports merely to effectuate them. The rhetoric of wills law tends to obscure this interdependence by focusing on the self-expressive aspect of will-making and on the will-reader's obligation not to judge the wishes expressed in the will. Traditional discussions of wills tend to emphasize the fact that, unlike other docuinents, wills are ambulatory and revocable ${ }^{72}$-colloquially, "a will speaks at death." To the extent that a will is an expression of autonomy and self-determination, ${ }^{73}$ what it

70. Sarat \& Felstiner, supra note 68, at 742 (footnote omitted); see also SHAFFER, supra note 69, at 142 ("Lawyers cannot perform even everyday psychotherapy for death anxiety if they continue to treat will-drafting as a form of black magic, carried out in Elizabethan English, with canned forms and ten minute interviews.").

71. This is a point that has received more extensive and sophisticated treatment elsewhere. See, e.g., RICHARD RORTY, CONTINGENCY, IRONY, AND SOLIDARITY 3-22 (1989); Peller, supra note 33, at 1159-70; James B. White, Thinking About Our Language, 96 YALE L.J. 1960 (1987).

72. See, e.g., Thomas E. ATKinson, Handbook of the LaW of Wills 1 (2d ed. 1953); 1 PAGE ON WILLS, supra note 11 , § 1.2, at 3.

73. See supra text accompanying notes 12-14. 
can be expected to communicate is the testator's unique and personal ideas, ${ }^{74}$ this notion is colloquially expressed in the phrase "no will has a brother." The purpose of confining interpretation to the words of the will-like the accepted purpose of the Wills Act itself-is to protect individualism. Limiting attention to the reliably evidenced, authenticated words of the will, and excluding less trustworthy evidence, ensures that private decisions expressed in proper and objective form will be protected against interference by others who may disapprove of or resent those decisions. In this model, the individual, solitary and separate, decides; the community, committed to respecting the individual's wishes, regulates only the form in which those wishes are expressed; others, however dismayed or disappointed, must defer. To protect this allocation of authority, the text of the will must be made authoritative.

The vision of will-making as a wholly private process assumes a divide between, on the one hand, an assumed domain of individual freedom and, on the other hand, a world of others who must be constrained from trampling upon that domain. Yet to envision a core of private decisions separate from and independent of the public institutions charged with implementing them is unrealistic. The idea that interpretation discovers (some aspect of) the testator's intent suggests that such intent preexists the law devoted to effectuating it. But the very notion of "testamentary imtent" presumes a legal regime of free testation; im a society in which assets owned at death are confiscable by the state for distribution to the needy, it is difficult to imagine that people would bother to formulate testamentary wishes. ${ }^{75}$ The private intent that wills law seeks to discover is in this sense a product of the public power that purports to recognize it.

This observation is not offered to prove that a testator completely lacks individual wishes with respect to the disposition of his property, but rather to suggest a more dynamic relation between private wishes and the public commitment to effectuate them. The ambulatory nature of wills may appear in the abstract to license

74. See, e.g., In re Estate of Pyle, 570 A.2d 1074, 1077 (Pa. Super. Ct. 1990) ("As most wills are seldom alike, it is necessary to interpret each will according to its own peculiar terms.").

75. Which is not to say that they might not find ways to make gifts before or after death. On the policies underlying testamentary freedom, see Mark L. Asher, Curtailing Inherited Wealth, 89 MICH. L. REV. 69, 100-21 (1990). 
unfettered expression of individual choices; but it has quite another significance as well: The testator cannot carry out his own commands, but instead is dependent on others to read the will and put its commands into effect. The testator thus must by necessity write for others. ${ }^{76}$ This necessary consciousness of others and of the testator's dependence on them has further implications for the conception of a will as an instrument expressive of the testator's own unique values. The testator's consciousness of a future audience of unknown others surely affects, to some degree, the wishes he forms.

Many "public" forces affect the testator's decisions. One way in which the world of others influences the formation of testamentary wishes is through the intervention of an attorney-often considered a mere facilitator who records, in legally effective form, ideas originating from the testator. ${ }^{n}$ However, the attorney's role can be far more active. Often the responsible attorney brings to the testator's attention an eventuality the testator did not before consider, thereby "causing" the testator to have an intention he would not otherwise have had. One empirical study found that "[t]he attorney who typically drafts the will may have influenced the testate's distributive pattern by suggesting that certain will provisions are customary. $" 78$

Of course, once the testator becomes conscious of a possibility, the decision as to the disposition to be made under these nowanticipated circumstances is up to the testator, and the decision is arguably no less the testator's for having been made at the attorney's urging. In this view, the testator's signature at the end of the will evidences the choice to adopt as his own the attorneysuggested dispositive scheme. The large number of wills contested

76. Commenting on "orthodox" wills theory, Professor Curtis says:

The grave fault of the orthodox theory is that it assumes that the author retains control over his words after he has uttered them. How can he? He knows that his words are to be applied by others and in the future, by others over whoin he may have no control except by litigation, and in a future in which he may have no part.

Curtis, supra note 40 , at 423.

77. One set of reasons to question this formulation of the attorney's role is explored supra in the text accompanying notes 60-70.

78. Mary Louise Fellows et al., An Empirical Study of the Illinois Statutory Estate Plan, 1976 U. ILL. L. FORUM 717, 722; see also SUSSMAN ET AL., supra note 67, at 217 (arguing that "it is impossible to overlook the fact that the lawyer, like his client, is a product of his culture and that in subtle and unobtrusive ways he influences his client to make the right decision"). 
on the grounds of scrivener error suggests, however, that often there is little association between the testator's signature and intent to include the particular will provisions above it. ${ }^{79}$

Even if an attorney is not involved, will-making is not an entirely private process. Wills are not uncommon in this society. ${ }^{80}$ Will-making is to some degree a conventional activity, the typical patterns of which are widely known. ${ }^{81}$ These conventions are not necessarily explicitly perceived or consciously chosen; they may operate before choice and, indeed, may in part "structure choice, preference, desire, and perception." De Decisions thought to lie solely with the individual-the decision to make a will at all, the decision to give this or that item of property to one or another person-may be influenced by the testator's sense of what he "ought to do," or of what "most people do."83 My father's complaints about his own will illustrate this phenomenon: He apparently felt he had to make provisions that were in some universal or general sense "fair," even if those provisions conflicted with al-

79. See Langbein \& Waggoner, supra note 11, at 521-22.

80. For empirical studies examining, inter alia, the frequency of testation, see Carole Shammas eT al, INHERITANCE IN AMERICA fROM Colonial TMMes to the PRESENT (1987); SUSSMAN ET AL., supra note 67, at 64-81; Olin L. Browder, Jr., Recent Patterns of Testate Succession in the United States and England, 67 MICH. L. REV. 1303 (1969); Allison Dunham, The Method, Process and Frequency of Wealth Transmission at Death, 30 U. CHI. L. REV. 241 (1963).

It is clear that the probate system has declined dramatically in importance relative to non-probate transfers. Langbein, supra note 12 , at 1108 . Nothing in the literature suggests, however, that wills have become unimportant or rare.

81. For example, all the studies cited supra note 80 showed that a large majority of decedents survived by a spouse left all their property to the spouse, even if they were also survived by issue. Where decedents were survived by issue but not by spouses, they tended to leave their estates to their issue. Similar results were reached in studies that asked people about their hypothetical dispositive preferences (as opposed to studies based on examination of actual wills). See Mary Louise Fellows et al., Public Attitudes About Property Distribution at Death and Intestate Succession Laws in the United States, 1978 AM. B. Found. RES. J. 319; Fellows et al., supra note 78, at 727-36; see also SHAMMAS ET AL, supra note 80, at 207 ("Despite almost complete testamentary freedoin, Americans have whenever possible limited their substantial bequests to spouse, sons, and daughters.").

82. J.M. Balkin, Ideology as Constraint, 43 STAN. L. REv. 1133, 1150-51 (1991) (book review) (emphasis added).

83. See JefFrey P. Rosenfeld, ThE LEgACY OF AGING 29-30 (1979) (arguing that within the American systein of inheritance the norm of free testation is matched by a counternorm of devotion to the family);'see also SCHAFFER, supra note 69 , at 82-83 (suggesting that wills clients feel a "inoral imperative" to provide for dependents after death). 
ternative dispositions he wished in some less abstract way he could have made.

Even if a testator chooses not to conform to conventional dispositive patterns, those patterns may nonetheless exert an influence on the terms of his will. The testator is likely to be aware that the world of others for whom he writes is also familiar with the conventional patterns of wills and that, based on these patterns, those others may have expectations about what the will is likely to or should say. The testator may write to meet those expectations or to explain why those expectations are being defeated. ${ }^{84}$

The point is not that conventions or expectations determine or control what a testator does. Innumerable factors unique to the individual testator-his personal circumstances of age, wealth, family, personality, attitude toward death, etc.-are all part of the complex decision to make a particular will at a particular time. Rather, the point is that awareness of others and their expectations is also an integral part of the formation of the testator's "private" intent.

\section{The Meaning of Words and Modernist Consciousness}

A brief recapitulation at this point will help to locate wills law and its problems within the realm of modern legal theory. On a doctrinal level, the task of will interpretation has come to be defimed in terms of the discovery of the meaning of words. The inquiry is considerably more narrow than might be expected in an area of law whose stated object is the effectuation of individuals' actual wishes. Yet the limitation of the inquiry has been understood as necessary: If a testator is to govern the terms of his will, then the will's formally authenticated words must control, lest the Wills Act be threatened or, worse, others substitute their wishes for the testator's. The problem is conceived as involving the ap-

84. The existence of expectations on the part of those who see themselves as the natural objects of a testator's beneficence is to some degree confirmed by the estate planning literature geared to the possibility of a will contest where a testator plans to depart from typical dispositions in favor of family. See, e.g., Leon Jaworski, The Will Contest, 10 BAYLOR L. REV. 87, 89-93 (1958); Jan E. Rein-Francovich, An Ounce of Prevention: Grounds for Upsetting Wills and Will Substitutes, 20 GoNZ. L. REV. 1, 64-67 (1984). 
propriate way to protect the private realm of the testator's decisional authority.

Whatever its conceptual coherence, the meaning-of-words model of will interpretation can be understood to reflect a plausible set of aspirations about the problem of testamentary "communication." The person whose ideas and wishes are legally determinative is not going to be present to explain them. If that person knows exactly what he wants and says exactly what he has thought, no explanation will be needed. His words-the instrument's expressed commands-will represent, i.e., mirror, the choices he has made in his mind. ${ }^{85}$ Those mirrored choices will then control, over the choices that might have been made by others.

To work, the scheme requires self-reliance in the use of language: The will's author must harness language to his ends. Such self-reliance functions affirmatively to present the author's "internal" wishes to the "outside" world of survivors. It also functions negatively to constrain those survivors from stepping beyond their proper role as "mere" readers.

The affirmative side of the meaning-of-words model locates the author's individuality within himself; his personhood must be brought out through externally perceivable manifestations. The individual is thus clearly bounded. ${ }^{86}$ The negative side of the model highlights whom the individual is bounded from: the world of potentially threatening others, whose power over the individual must be carefully curtailed. The doctrines of will interpretation in this way seem, like so many doctrines of private law, an attempt to mediate an assumed sharp divide between the individual and the collective. ${ }^{87}$

85. On the notions of representation and mirroring, see RICHARD RORTY, PHILOSOPHY AND THE MIRROR OF NATURE 257-312 (1979); Balkm, supra note 33, at 760; and Peller, supra note 33, at 1175.

86. See Jennifer Nedelsky, Law, Boundaries, and the Bounded Self, 30 REPRESENTATIONS, Spring 1990, at 162, 168 (noting that "the image of protective boundaries as essential to the integrity and autonomy of the self is deep and pervasive in our culture"); see also Gregory S. Alexander, Dilemmas of Group Autonomy: Residential Associations and Commmunity, 75 CORNELL L. REV. 1, 59-61 (1989) (suggesting that "walls" can function like barriers and that the dialogue necessary to creating genuine community cannot occur in the presence of walls).

87. See, e.g., Dalton, supra note 9, at 1010 ("The underlying notion [of contract discourse] has been that to the extent contract doctrine is 'private,' or controlled by the parties, it guarantees individual autonomy or freedom; to the extent it is 'public,' or con- 
In both its view of language as the outside representation of inner thoughts and its view of the will-writer as an individual isolated from the collective, wills law seems thoroughly "modernist" in orientation. ${ }^{88}$ Wills law shares with liberal legalism assumptions that identify each adult individual "as a distinct being having unique wants and a capacity for self-reliance .... Those wants and preferences are subjective and taken as givens-free from second-guessing by society. Society and the polity must both be restrained from interfering with each unique self ...."89 Like both mainstream legal theorists and their critics, wills law assumes that interpretation must be somehow constrained and that "[i]f there are no constraints, judges and other powerful legal actors will be free to impose their values." 90

Based on these assumptions about language, the self, and the dangers of imposition, wills law seeks constraint in the text of wills. In order to protect the individual from the world of potentially hostile others, the meaning-of-words model of interpretation limits permissibly searched-for thoughts to those that can be connected in a more-or-less direct way to the formally executed words of the will.

Ironically, this attempt to preserve the domain of individuality from collective threat has the perverse consequence of abstracting individuals, reducing them to the sum of their verbal choices. ${ }^{91}$

trolled by the state, it infringes individual autonomy."); Nedelsky, supra note 86, at 167 ("The primary content of ... [the] conception of autonomy [expressed in American property law] is protection from the intrusion of the collective.").

88. See Dennis Patterson, Postmodemism/Femmism/Law, 77 CoRnell L. Rev. 254, 266-68 (1992) (describing how, in the modernist view, "[I]anguage either refers to objects in the world or is expressive of the attitudes, preferences, or emotions of the speaker"; to the modernist individualist, "society is composed simply of 'social atoms' ").

89. Martha Minow, Making All the Difference 162 (1990). Professor Minow argues that these assumptions are shared alike by law and economics scholars, rights theorists, and Critical Legal Studies scholars. Id. at 162 \& 165 n.59. Professor West associates these assumptions with "patriarchal jurisprudence." Robin West, Jurisprudence and Gender, 55 U. CHI. L. REV. 1 (1988).

90. Wimter, supra note 2, at 1596; see also Balkin, supra note 82, at 1141 ("If one separates social rules and individual will ...., the greatest problem for jurisprudence is what we might call the 'rogue judge'-the decisionmaker who wants to follow his or her own political agenda, and who must be hemmed in by an objective doctrinal structure.").

91. See MiNow, supra note 89, at 162 (noting that the identification of individuality with choice-making in effect dehumanizes those who, like children and mentally imcompetent persons, are presumed unable to form preferences); Thomas Morawetz, Persons Without History: Liberal Theory and Human Experience, 66 B.U. L. REv. 1013, 1020 (1986) (Liberal theorists who defend neutrality offer a "thin" theory of human nature, "commit- 
Testators' only personalities reside in their potentially idiosyncratic use of words. There is something deeply dissatisfying about a system that protects individuals only by depriving them of their humanity.

From an increasing variety of directions, the notion that drives this unsatisfying system-the notion of self divided from community-has come under attack." Just as "subjective" ideas are affected by the "objective" language in which they are expressed ${ }^{93}$ and "private" wishes are affected by "public" forces, ${ }^{94}$ so the relationship between the individual and the collective is less one of opposition than of mutual dependence. As Professor Minow has put it: "Autonomy, even as an aspiration, is the invention of a cultural and linguistic community .... As a psychological matter, the very experience of a bounded personal identity requires not just one individual but many, who help constitute the boundaries." other words, "people do not exist in isolation, but in social and political relations. People develop their predispositions, their interests, their autonomy-in short, their identity-in large part out of these relations." $" 1 \%$

Thus the "private" realm in which a testator is traditionally understood to decide is not isolated from "public" forces. No testator can write without consciousness of others; and that consciousness does not limit, but instead defines the very "freedom" he is exercising. The point is not that a testator has no autonomy, but rather that self-determination is a process quite different from

ted only to the notion of persons ... as loci of arbitrary preferences . . . . Living well, in this view, means being in a position to choose and to satisfy one's choices."); see also Pierre Schlag, Normativity and the Politics of Eorm, 139 U. PA. L. REv. 801, 807 (1991):

Now, you might think: well, this [equating people with the sum of their verbal choices] is not so bad. At least we get to choose. We are free and we can choose which way to go. But, of course, we are not free $\ldots$. On the contrary, we (you and I) have been constituted as the kind of beings, the kind of thinkers who compulsively treat every intellectual, social, or legal event as calling for a choice. We inust choose.

92. See MiNow, supra note 89 , at 192 (suggesting that the challenge has been made in field after field of scholarship). The challenge is sometimes specifically associated with feininism. See, e.g., Jennifer Nedelsky, Reconceiving Autonomy: Sources, Thoughts and Possibilities, 1 YALE J.L. \& FEMINISM 7 (1989). The challenge has also been associated with postmodernisin. See, e.g., Pierre Schlag, The Problem of the Subject, 69 TEX. L. REV. 1627 (1991); Winter, supra note 2.

93. See supra Section B.

94. See supra Section C.

95. MINow, supra note 89 , at 300.

96. Nedelsky, supra note 92 , at 21 . 
that envisioned by the traditional understanding of will interpretation. The very idea of freedom of testation needs to be rethought. "If individuals are socially constructed, then their freedom will not consist in thoughts and actions which exist separate and apart from culture. Rather, their freedom always consists in their thoughts and actions as socially constructed individuals."

\section{WILLS AS STORIES}

Stories are one important way in which humans use their shared culture to cross intersubjective bounds. ${ }^{98}$ "One fundamental characteristic of human life is that we all tell stories, all the time, about ourselves and others, both in the law and out of it." phenoinenon may explain how, despite all their differences, individuals communicate with the world of others quite successfully much of the time. ${ }^{100}$ Through stories, individuals "take experience and configure it in a conventional and comprehensible form."101 Just as individuals manage to speak across and through their boundaries, so wills speak across time, despite their authors' absence. ${ }^{102}$ If the law of wills were less wedded to traditional, modernist dichotomies between subjective and objective, between private and public, it might understand wills as a form of storytelling: Wills "tell" testators' stories about the disposition of their property after death. Wills are but one more way in which individuals rely on and use culture, which both "construct[s] and enable[s] subjectivity"103 to make and share meaning. ${ }^{104}$

As with other stories, the will-story has a conventional form and content; as with other stories, the will-story's conventional form and content can be adapted in an almost infinite variety of

97. J.M. Balkin, The Promise of Legal Semiotics, 69 TEX. L. REv. 1831, 1848 (1991).

98. See Gerald P. Lopez, Lay Lawyering, 32 UCLA L. REV. 1, 3 (1984) ("Human beings think about social interaction in story form.").

99. WHrTE, supra note 62, at 169.

100. Winter, The Cognitive Dimension, supra note 8, at 2245 (observing that "our everyday experience consists of meaningful, even if imperfect, intersubjective communication").

101. Id. at 2228.

102. When it is colloquially said that "a will speaks at death," the einphasis tends to be placed on the words "at death," highlighting the fact that the will's author is never available to explain it. I suggest that the emphasis belongs on the verb.

103. Winter, supra note 2, at 1601 .

104. Id. at 1607. 
ways to express an individual's unique ideas. The will's familiar structure and subject make it recognizable to readers, telling them in general what to expect. The will's pliant structure permits expression of innumerable variations on common themes. Readers of a story do not seek merely to decode the meaning of words; neither should readers of a will. When a will's literal commands have given rise to an interpretive dispute, we are more likely to effectuate the testator's wishes-and thus to fulfill the accepted objectives of wills law-by seeking the story behind those commands rather than by seeking only to define the terms used in formulating the commands.

\section{A. The Will as a Story-Type or Stock Story}

The understanding of wills as stories begins with an understanding that the conventional patterns of wills and the expectations they generate cannot help but have an impact on the reading as well as on the writing of wills. Indeed, the activity of "interpreting" a will would be incomprehensible without some preexisting understanding of what a will is and does. ${ }^{105}$ Imagine a signed and dated paper on which only the following handwritten words appear:

\section{I give all to George not Paul.}

A reader confronting this paper can "find," among other things, a poem, a meaningless scribble, a notation of graffiti seen in a public restroom. An interpreter told that the paper is a holographic will is likely to "find" a devise of the entirety of the testator's property to a single individual to the exclusion of another. ${ }^{106}$ This example suggests that wills function as a genre, "a conventional function of language, a particular relation to the world which

105. The notion of will-making and will-reading as activities based on convention owes something to the writings of Stanley Fish. See STANLEY FISH, IS THERE A TEXT IN THIS Class? 268-92 (1980); Stanley Fish, Dennis Martinez and the Uses of Theory, 96 YalE L.J. 1773 (1987).

For a thoughtful discussion of how social and legal conventions work, see Balkin, supra note 82.

106. For a marvelous account of the confusion arising when such a paper is not clearly identified as a holograph, see Thomas C. Grey, The Hermeneutics File, 58 S. CAL. L. REV. 211 (1985). 
serves as a norm or expectation to guide the reader in his encounter with the text." 107 What an interpreter "finds" in a will is a function not only of what the testator placed there, but also of what the genre teaches must be in it.

Like testators, interpreters are aware of customary patterns of disposition and have expectations about what the will is likely to say. ${ }^{108}$ Although the doctrine and rhetoric of wills law makes much of testators' freedom to be arbitrary or foolish in the disposition of property, the very notions of "arbitrariness" and "foolishness" imply a concept of "regular" (not arbitrary) and "wise" (not foolish) dispositions. In this sense, wills can be seen as a story-type or stock story ${ }^{109}$ with "characters, story lines, and built-in resolutions embody[ing] commonly shared cultural views about the way things are and should be done ...." Such stories "help us interpret the everyday world with limited information and help us make choices about asserting our own needs and responding to other people."111

The perception of wills as a story-type or stock story helps explain why and how individuals unsophisticated about law "know" what a will is and what it does. ${ }^{112}$ The use of stock stories "resolves ambiguity and complements 'given' information with much 'assumed'- information."113 The will story-type is general and schematic; it permits a limitless number of particular instantiations. ${ }^{114}$

107. Jonathan D. CULler, Structuralist PoEtics 136 (1975).

108. Cf. Scheppele, supra note 58, at 2090 ("Observers, even those not directly involved in a dispute, bring with them a conceptual scheme already formed, a set of presuppositions and expectations, that influences what they see and report."); see also supra note 81 and accompanying text.

109. See Lopez, supra note 98, at 3 (defiming "stock story").

110. Id. at 9; see also WHITE, supra note 62 , at 172 (telling a story is never a purely private act, but implies a community).

111. Lopez, supra note 98, at 3; see also Winter, The Cognitive Dimension, supra note 8 , at 2233 (stock stories are used by individuals within a given culture to "organize the diverse inputs of daily life into meaningful gestalts that relate that which is 'relevant' and ignore that which is not").

112. See Winter, The Cognitive Dimension, supra note 8, at 2252 ("The narrator does not tell his or her story from the raw, unmediated data of life, but rather assembles and makes use of the preexisting cultural ICMs [Idealized Cognitive Models] with which he or she apprehends the world. The narrator then configures these nuclei to form a recognizable story-pattern with an apprehensible meaning.").

113. Lopez, supra note 98 , at 6.

114. Wimter, The Cognitive Dimension, supra note 8, at 2252-53; see also Balkin, supra note 82 , at $1151-52$ (suggesting that although imdividuals in a society may share conventions or ideologies, those individuals "do not share exactly the same beliefs"). 
When making a will, the testator configures the individual elements of his own personal plan and expresses them in a manner recognizable and comprehensible to the audience for which he writes. ${ }^{115}$ The will is then read with expectations formed by prior wills-real or imagined. ${ }^{116}$ The reader processes the individual elements of a particular will by "fitting" them into the larger, familiar story structure, and by comparing and contrasting them to the elements he anticipates. ${ }^{117}$ What the reader anticipates affects how she reads: what is likely to seem clear, is clear, what is likely to seem unclear, is unclear. ${ }^{118}$ Indeed, it is possible that interpretive "problems" are most likely to be perceived when the will departs from anticipated patterns.

\section{B. The Story Behind the Commands of the Will}

Testators have particular stories they seek to tell through the will "stock." Sometimes these stories can be reduced to a set of commands: "I give all my property [as a reward] to my [loyal] son George." More often, the stories are richer, more detailed and emotional, than can be captured fully in a set of instructions concerning the disposition of property.

Where a will's verbal commands seem clear (in the sense of being complete, comprehensible, and in accord with the reader's expectations), the richness of the "under-story" can be comfortably

115. Winter, The Cognitive Dimension, supra note 8, at 2270; see also Lopez, supra note 98 , at 28 ("A storyteller . . . always makes assumptions about his audience . . . . [A] storyteller originally shapes the narrative on the basis of the anticipated and imagined 'proddings and promptings' of the audience . . . .").

116. See Winter, The Cognitive Dimension, supra note 8, at 2252 ("The reader inevitably transfuses the narrative with his or her own reconstructive effort, decoding the plot and the message in relation to the ICMs [Idealized Cognitive Models] that the reader brings to the process of understanding and interpretation.") (footnote omitted).

117. See BENNETT \& FELDMAN, supra note 8, at 62 ("[S]tories . . engage some general cognitive models of social action against which particular networks of story connections can be judged for completeness, consistency, and aunbiguity."); see also Lopez, supra note 98, at 15-20; Winter, The Cognitive Dimension, supra note 8, at 2272.

118. Cf. Nancy Pennington \& Reid Hastie, A Cognitive Theory of Juror Decision Making: The Story Model, 13 CARDozo L. REv, 519 (1991). Professors Pennington and Hastie point out:

[E]xpectations about the kinds of information necessary to make a story tell the juror when important pieces of the explanation structure are missing and when inferences must be inade. Knowledge about the structure of stories allows the juror to forn an opinion concerning the completeness of the evidence, or the Id. at 527. extent to which a story has all its parts. 
ignored; the words of the will can be followed. But where a will's words are unclear (incomplete, internally inconsistent, ambiguous, at odds with expectations), the under-story is what we most want to know. When we ask, with respect to a disposition alleged to be ambiguous, "What was the testator trying to do?," we do not mean, "Did the testator use a particular word in this sense or that?" We mean, "What was he trying to accomplish here? What is his story? Who were the people he loved?" and the like.

This desire to hear the story underneath the will accounts for the persistent frustration with interpretive doctrines that, by making the issue one of word-meaning, render much evidence of intent substantively irrelevant. ${ }^{119}$ What we "know" of a testator (or any other person or event) is a function of the evidence available to us. To the extent that evidence is actually excluded, we will "know" less, or differently.

Studies of courtroom and law-office interactions suggest that clients $^{120}$ and witnesses ${ }^{121}$ tend to see the "facts" in narrative or story form, and that factfinders understand the evidence offered them by assembling it into comprehensible stories. ${ }^{12}$ Excluding evidence of the will's under-story altogether, or admitting it (or pieces of it) only in the word-meaning context, ${ }^{123}$ may deprive us of what we actually need in order to come to know who the testator was as a person..$^{124}$ Knowing his story, in contrast, might permit us to form an imaginative relationship with him, to make some sort of connection. ${ }^{125}$

119. See supra text accompanying notes $54-58$.

120. See Sarat \& Felstiner, supra note 68.

121. See William O'Barr \& John Conley, Litigant Satisfaction Versus Legal Adequacy in Small Claims Court Narratives, 19 L. \& Soc'Y REv. 661, 665-67 (1985).

122. BENNETT \& FELDMAN, supra note 8; Pennington \& Hastie, supra note 118; see also Maynard, supra note 65, at 476-77 ("[T] he major features of a case are not prior to or independent of narratives; instead they come to life through narrative practices by which a teller makes thein manifest and a listener makes inferences and responds accordingly.").

123. On the epistemological importance of the context in which evidence is admitted, see Ronald J. Allen, The Nature of Juridical Proof, 13 CARDozo L. REv. 373, 385-92 (1991) (contrastimg probabilistic with historiographic approaches to evidentiary proof).

124. See Lynne N. Henderson, Legality and Empathy, 85 MiCH. L. REV. 1574, 1592 (1987) (describing the use of narrative to create "affective understanding").

125. See Delgado, supra note 6, at 2412 ("[S]tories create their own bonds . . . ."); id. at 2414 (stories can build community, consensus, "a common culture of shared understandings"); see also Joseph W. Singer, Persuasion, 87 MICH. L. REv. 2442, 2458 (1989) (" $[P]$ ersuasion starts by creating a relationship between oneself and others ... [and] 
Consider the following will provisions:

THIRD: I give to my daughter ... any items of my personal property including household furniture which she elects to take, subject to the provision, however, that if my wife ... survives me, my wife may enjoy the use of said personal property and household furniture during her lifetime if my wife so elects.

FOURTH: All the rest, residue, and remainder of my estate, both real and personal of whatever kind and nature, and wheresoever situated, I give, devise and bequeath to my wife ... to be hers absolutely and forever.

Assume that the testator, who drew this will himself, owned no real property at either the time the will was executed or the time of his death. Assume further that the daughter and the wife named as beneficiaries were unrelated: the daughter was the product of a first marriage, which terminated with the death of the testator's first wife, and the wife named in the will was the daughter's stepmother, the testator's second wife.

A typical interpretive contest that might arise from a will of this sort would involve the meaning of the term "personal property" in clause "THIRD." In case after case involving wills with similar provisions-and there is an alarmingly high number of them ${ }^{126}$ - the devisee of the personal property (the daughter, in this scenario) claims that she is effectively the sole beneficiary of the will. "Personal property," she typically argues, means all property other than realty; there being no real property, all of the testator's assets-including money, stocks and other intangibles as well as tangible personalty-should pass to her if she "elects" to take them. ${ }^{127}$

makes them aware of the connections they already have.").

126. The provision for the wife's hife estate is unusual; the rest is fairly common. See, e.g., Fitzgerald v. Salvation Army (In re Estate of Graham), 316 P.2d 945 (Cal. 1957). Lamentably, many of the litigated wills were drafted by attorneys, and one of the issues raised in the cases involving those wills is whether the court should admit evidence from the scrivener. See, e.g., Lesher v. Florida Nat'l Bank of Gainesville (In re Estate of Lesher), 365 So. 2d 815 (Fla. Dist. Ct. App. 1979); Breckner v. Prestwood, 600 S.W.2d 52 (Mo. Ct. App. 1980). In Estate of McKenna, 489 A.2d 862, 868 n.7 (Pa. Super. Ct. 1985), the court expressly chided connsel for failing "to use clear and precise language to set forth the testator's imtent."

127. In the cases where the estate includes real property, the devisee of the personalty clains all the personal property, intangible as well as tangible. 
Courts are extremely unreceptive to such claims and hold in the overwhelming majority of these cases that the devisee should receive only items of tangible personalty. ${ }^{128}$ The reasoning used across the large number of cases is remarkably similar. The issue is framed as. whether the testator used the words "personal property" in their technical as opposed to their ordinary or colloquial sense-i.e., the issue is framed as one concerning the meaning of the words the testator used. Thus framed, the issue can almost always be resolved by reference to the face of the will. The court may invoke the doctrine of ejusdem generis, under which the general term "personal property" is deemed to be qualified and limited by the particular illustrations that follow it. ${ }^{129}$ Alternatively, the court may note that if "personal property" is interpreted broadly, then the will's residuary clause will be rendered meaningless, violating the constructional maxim that courts should give effect to all of a will's words, if possible. ${ }^{130}$ Finally, the court may find some other will provision that also seems to deal with personal property, thus making it unlikely that all the personalty had already been disposed of. ${ }^{131}$ And in those few cases that cannot be resolved solely by reference to the face of the will, extrinsic evi-

128. 80 AM. JUR. 2D Wills $\S 1249$ (1975) ("While it is clear that the term 'personal property' is sufficiently broad ... to include all forms of property other than land ...., in a majority of cases the courts have ... construed the term as carrying a restricted rather than a broad signification."). For a collection of cases, see Annotation, What Passes Under the Term "Personal Property" in Will, 94 A.L.R.2d 1106 (1964). See also cases cited infra notes 129-32.

129. See, e.g., Bird v. Dishong (In re Estate of Horne), 171 So. 2d 14, 16-21 (Fla. Dist. Ct. App. 1965); Leroy v. Kirk, 277 A.2d 611, 614-15 (Md. 1971); Breckner, 600 S.W.2d at 57; In re Estate of Weissenborn, 466 P.2d 536, 538-39 (Wash. Ct. App. 1970). But see Martin v. First Nat'l Bank of Mobile, 412 So. 2d 250, 253 (Ala. 1982) (holding primciple of ejusdem generis does not apply where the executor is given express authority to determine what objects of property are to be included in the description of "personal property"); Hays v. Coe, 595 A.2d 484, 486-87 (Md. Ct. Spec. App. 1991) (holding ejusdem generis inapplicable to devise of "all of my personal property, including but not limited to furniture and fixtures").

130. See, e.g., Fitzgerald, 316 P.2d at 947; Feighan v. Motto, 144 N.E.2d 510, 511 (Ohio Prob. Ct. 1955); McKenna, 489 A.2d at 866-67.

131. See, e.g., Breckner, 600 S.W.2d at 58; Lee v. Hale, 562 S.W.2d 190, 193 (Tenn. 1978). Compare Lesher, 365 So. $2 d$ at 818 (holding that where the devise is of personal property "'physically situated [in] Pennsylvania'... . [ $t$ ] he term 'physically situated' would tend to indicate that [the] term 'personal property' referred to tangible personal property") with Jacoway v. Brittain, 360 So. $2 d$ 306, 307-08 (Ala. 1978) (devise of "all my personal property, located in my home, or on my property" held to include intangible assets at the bank where the passbook and the key to the safety deposit box were on the testator's property). 
dence of intent to limit the gift to tangible personalty can be smuggled in as one of the circumstances surrounding the testator at the time of the will's execution ${ }^{132}$ - a long-established exception to the rule barring extrinsic evidence, which, as I discuss below, is quite different from a storytelling approach. ${ }^{133}$

Now on one level, these approaches to the constructional issue are predictable. They are exactly what one would expect under the meaning-of-words model of will interpretation. And the results reached do not seem wrong per se. By interpreting the words "personal property" to mean "tangible personalty," the court ensures that in most cases all of the devisees get something. This outcome seems fair, and it is more logical than finding, in effect, that a testator bothered to name someone a beneficiary but neglected to give anything to that person.

Yet on another level, the approaches taken by the courts are just plain strange. Although the courts' opinions begin with the usual homilies to the primacy of the testator's individual intent, they in fact treat the wills as abstract and more-or-less fungible puzzles into which all the word-pieces must be made to fit. A capable lawyer can almost always manipulate either the "plain meaning rule" or its numerous exceptions to permit investigation of at least a few facts extrinsic to a will's language as long as she can argue (and what capable lawyer cannot?) that the evidence is being offered to explicate some word of the will. ${ }^{134}$ Squeezing evidence into this limited word-meaning context is not a harmless or neutral strategy. ${ }^{135}$ The focus remains on the words, not on the complex motives by which they were produced. The discussions are bloodless. One would hardly know that any actual people were involved-only "testators," "beneficiaries," "scriveners," and "resid-

132. See, e.g., Wachovia Bank \& Trust Co. v. Wolfe, 91 S.E.2d 246, 250 (N.C. 1956); McKenna, 489 A.2d at 866-67; see also Fitzgerald, 316 P.2d at 946 (holding that probate code provision requiring that technical words in a will be taken in their technical sense, unless it appears that the testator was unfaniliar with that sense, contemplates admission of extrinsic evidence to assess whether the testator was acquainted with the technical sense of the words used).

133. On the rule permitting extrinsic evidence to establish the circumstances surrounding the execution of the will, see supra note 57. On the differences between that rule and the storytelling approach, see infra text accompanying notes 135-36.

134. See Langbein \& Waggoner, supra note 11 , at 529-35.

135. Cf. Scheppele, supra note 58, at 2097 ("[F]raming stories narrowly around 'the trouble' at issue ... [can] work to silence the accounts of outsiders . ..."). 
uary devisees." And none of these folks have any discernible personalities at all.

Or maybe one only finds this strange if one already knows the story of the will. In the case of the will quoted above, I know it quite well: It is my father's. There are, it turns out, many facts and circumstances that might help explain what my father thought he was doing in those two convoluted paragraphs-facts about the different kinds of personalty he owned, his relationships with me and my stepmother, his understanding of the relationship my stepmother and I had, and so on. Almost everyone with whom I have spoken about the will has asked about these matters, and several colleagues to whom I have shown this Essay have suggested that I describe the facts here. But, of course, under the governing rules and precedents none of these facts would matter much. ${ }^{136}$ That is just my point. Left alone, we may think in terms of stories; when we are unsure what was meant to happen, we may seek stories out. The law proceeds otherwise. As the law sees him, my father was just another testator, not a real man, and his story-all the complex things he was and did-doesn't count. From where I sit, it's a funny view of the freedom of testation.

Real people, not abstractions, write wills-and real people read them. If wills law's individualist rhetoric is to be made meaningful, interpretation must seek the human voice behind every will. It will not find it in examining the usage of words; it will not find it in decoded commands. The human author of the will is to be found in his story.

\section{The Danger of Ignoring Individual Stories}

Explanations of the meaning-of-words model of will interpretation make much of the evils that might result if the will's words are not made the sole focus. These explanations suggest a dichotomy between interpretive methodologies that are neutral, impartial, reliable, and predictable, and those that are untrustworthy, biased, and unreliable. This dichotomy is false. Some of the same forces that limit the freedom of the testator also limit the freedom of the reader. Neutrality, impartiality, reliability, and predictability are themselves (contestable) values. To hold those values is to have a

136. As things worked out, they didn't: My stepmother and I settled the estate by agreement. But that's another story. 
position, to be partial. ${ }^{137}$ "The 'neutral observer's' point of view is no less a point of view than any other." 138 To exclude or marginalize the testator's story in the name of neutrality risks exactly the imposition that the meaning-of-words model purports to avoid. Someone's story will emerge from interpretation proceedings; the only question is whose.

The factfinder (for simplicity's sake, call her a judge) in a will interpretation case, like any other reader of any other text, necessarily encounters the instrument "in a situation which unavoidably includes the beliefs that the reader holds." ${ }^{139}$ As a member of a culture in which the making of wills is to some degree a conventional activity, the judge, like the testator himself, is likely to have expectations about the dispositive patterns to which the will is going to conform, such as provisions for a surviving spouse or for children. ${ }^{140}$ These beliefs form a context for even the most literal readings of a will ${ }^{141}$ - a context all the more powerful because it tends to be unrecognized. ${ }^{142}$ "All decisionmaking makes use of ideological constructions of social reality. What we call 'non-ideological' decisions are ideological decisions whose ideology is simply not noticed." This "outside" context or ideology can-

137. Minow, supra note 89 , at 376 ("Impartiality is the guise that partiality takes to seal bias against exposure ...."); Martha Minow, The Supreme Court 1986 Term-Foreword: Justice Engendered, 101 HARv. L. REV. 10, 75 (1987); cf. Martha Minow \& Elizabeth V. Spelman, Passion for Justice, 10 CARDozo L. REv. 37, 52 (1988) (expressing the view that a judge's aspirations to step beyond personal predilections are for nought if the judge fails to challenge her own point of view).

On the ambiguity of the concept of partiality, see Baron, supra note 3, at 83 n.23.

138. Scheppele, supra note 58 , at 2090.

139. Kenneth S. Abraham, Statutory Interpretation and Literary Theory: Some Common Concerns of an Unlikely Pair, in INTERPRETTNG LAW AND LITERATURE 115, 124 (Sanford Levinson \& Steven Mailloux eds., 1988); see also Kenneth L. Karst, Judging and Belonging, 61 S. CAL. L. REV. 1957, 1957-58 (1988) (arguing that a judge cannot leave her acculturation at the courtroom door).

140. See supra text accompanying notes 80-84.

141. See FiSH, supra note 105 , at 280 ("[A]ny reading that is plain and obvious in the light of some assumed purpose (and it is inpossible not to assume one) is a literal reading; but no reading is the literal reading in the sense that [it] is available apart from any purpose whatsoever.").

142. See Martha Minow \& Elizabeth V. Spelman, In Context, 63 S. CAL. L. REV. 1597,1605 (1990) ("Arguments over context ... may wrongly inply that we can ever escape context.").

143. Balkin, supra note 82 , at 1153; see also Mìnow \& Spelinan, supra note 137 , at 52 ("The very aspirational language of impersonality and objectivity, while aining to stretch the judge beyond personal prejudices, denies the need to acknowledge the impact of 
not help but have an impact on what the judge then finds "inside" the will. ${ }^{144}$

Consider, for example, a will typed on a testator's home typewriter making no provision for the testator's only child, Maxwell A. Smith, but devising substantial property to "Maxwell S. Smith," a distant cousin of the testator. Most judges-most people-would suspect a typographical error here. But what leads most readers to consider the proximity of the " $a$ " typewriter key to the " $\mathrm{s}$ " key has nothing to do with the words of the will. Instead, what raises the suspicion of error is the belief that people tend to (ought to?) prefer their children to more distant relatives in distributing property after death.

My point is not that this belief is wrong; indeed, there is empirical support for it. ${ }^{145}$ Rather, my point is that this belief, which is only a belief and which exists in the reader's mind independently of any particular will, counts as a fact in interpreting a will which appears to be at odds with it. Unless we are open to the possibility of an "under-story" in this instance, we risk limiting the testator's freedom (to disinherit a child ${ }^{146}$ ) under the guise of effectuating it. "There is a real risk of imposing one's own perspective by claiming already to be impartial and objective-by claiming, indeed, to be the kind of reasonable person whose standards provide the standards for judging the conduct of others."147

I am suggesting that individuals' stories, in all their richness and detail, can be used far more effectively than decoded words to actualize the system's goal of testamentary freedom. The claim is analogous to a claim sometimes made by outsiders and outsider jurisprudence ${ }^{148}$ that stories can be used to challenge and reduce

one's own perspective in the process of trying to see another's point of view.").

144. Catharine Wells, Situated Decisionmaking, 63 S. CAL. L. REv. 1727, 1743 (1990) ("What we see and hear is filtered and interpreted within a cognitive framework that is constructed largely from our own individual temperament and prior experience. Nonnative judgments in particular cases are strongly influenced by perceptions about the nature of the controversy withm this larger framework.") (footnote omitted).

145. See supra notes $80-81,83$ and accompanying text.

146. Preternitted heir statutes do not prohibit disinheritance. Like the formalities of the Wills Act, the requirements of pretermitted child statutes purport merely to regulate the forn in which the intention to disinherit must be expressed. See, e.g., UNIFORM PROBATE CODE § 2-302, 8 U.L.A. 90-91 (1983).

147. Minow \& Spelman, supra note 137, at 52 .

148. For a description and definition of these terns, see Matsuda, supra note 3, at 2323-26. 
the impact of the stereotypes or preconceptions that are instrumental to the perpetuation of power and domination in our society. ${ }^{149}$ If "we construct social reality by devising and passing on stories," power to create fact; those whose stories are not believed live in a legally sanctioned 'reality' that does not match their perceptions." "Counterstories" can be used to "challenge the received wisdoin" and to show that "there are possibilities for life other than the ones we live." ${ }^{\text {"S2 }}$ Such stories can attack complacency, heighten awareness, and "enable the listener and the teller to build a world richer than either could make alone." 153

Similarly, in the context of will interpretation, admission of the testator's story can help us see whether-and sometimes why-a testator chose to depart froin dispositive patterns that, however frequently adopted by others, are not right for him. What I have called the will's "under-story" can be used, like the outsider's "counterstory," to "invest[] text with feeling" and to give voice to those who can no longer express or explain their emotions directly. ${ }^{154}$ By attending to stories as well as words, we will hear "of persons and human meanings, not abstractions."155

Sometimes stories will be unnecessary. Most cases will not be contested. However "reinote" the words of attorney-drafted instruments may be from the ordinary stories told by the testator in his own words, ${ }^{156}$ the "legal words" can function tolerably well to

149. See Delgado, supra note 6 , at 2413 ("For many minority persons, the principal instrument of their subordination ... is the . . mindset by means of which members of the dominant group justify the world as it is, that is, with whites on top and browns and blacks at the bottom.") (footnotes omitted).

The ideas in this and the following paragraph are developed in a slightly different context in Baron, supra note 3, at 97-100.

150. Delgado, supra note 6 , at 2415.

151. Scheppele, supra note 58, at 2079 (footnotes omitted); see also Ball, supra note 3, at 2280-81 (suggesting that "[t]here is an American story of origins" and that while this story has "proved, at times, wonderfully transformative," it has also proved to be "sometimes incapacious, a rhetorical mode for closure and resistance to inclusiveness").

152. Delgado, supra note 6, at 2414; see also Matsuda, supra note 3, at 2324 (describing a methodology that attempts "to know history from the bottom").

153. Delgado, supra note 6 , at 2439.

For reservations about the potential of storytelling alone to effect change, see Ball, supra note 3, at 2281, and Baron, supra note 3, at 100-04.

154. See Delgado, supra note 6, at 2440.

155. Henderson, supra note 124, at 1592.

156. See supra text accompanying notes $60-64$. 
achieve dispositive objectives. Indeed, this is the result for which so many responsible estate planners strive, and mostly succeed. In contrast to the dilemmas posed by wills like my father's, no one wished to bring interpretive proceedings concerning my father-inlaw's will, for despite the complexity, obscurity, and legalism of its provisions, it accomplished exactly the ends he had in his own words stated to be those he desired. Put another way, the result of the will's technical commands tracked perfectly the story we understood to be underneath the will. The question is not what to do about the wills whose language "works" in this way. The question is what to do when the words are themselves confused or when the outcome is different from that which the survivors (and sometimes the scrivener) were led to expect. Here is where we need to be open, not just to word use, but to stories.

Acceptance of stories will not necessarily change the outcome im all-or even in many-of those cases that are contested. ${ }^{157}$ In some instances, there may be no way to know the testator's story, and thus no story to tell; the testator may not have spoken of his dispositive plans, nor recorded them in extrinsic documents such as memoranda or letters. In other cases, there may be too many conflicting stories, with no way to sort among them accurately. ${ }^{158}$ Finally, the story that emerges may be a tale of ambivalence, of the testator's inability to make the clear and final choices that the meaning-of-words model of interpretation contemplates. My father's will probably falls into this category. ${ }^{159}$

Yet while the gains from attending to stories may be speculative, the losses from ignoring them are not. The human aspects of the testator and his aspirations are lost in the meaning-of-words

157. Nor is there need to worry that openness to stories will increase the number of contests brought. This concern has been raised repeatedly in the analogous context of mistake correction, and it may be answered in the eloquent words of Justice Ellen Peters as follows: "There is no doubt that our increasingly fact-based jurisprudence serves to expose many apparently final dispositions to the juridical risk of unjustified judicial intervention. In the law of contracts, where the parol evidence rule has undergone considerable erosion, this risk has not been found to be unmanageable." Connecticut Junior Republic v. Sharon Hosp., 448 A.2d 190, 201 (Conn. 1982) (Peters, J., dissenting) (footnote omitted).

158. In the analogous context of mistake correction, Professors Langbein and Waggoner argue that a "clear and convincing evidence" standard can be used as a safeguard where extrinsic evidence is received. See Langbein \& Waggoner, supra note 11, at 526. Under such a standard, the will's "literal" meaning would prevail if the "stories" were truly in conflict.

159. For another example, see Grey, supra note 106, at 234. 
model. If testation is to be more than a game playable only by those who are sophisticated and receive able legal advice, then it is worth working to regain those human aspects. "[T]he quality of the human response [in a decision] is itself a dimension of substantive justice ...."160 We cannot, then, do justice without heightening decisionmakers' sensitivity to the human beings affected by their decisions. People are not merely the sum of their written words. By attending to testators' stories, we can build into the interpretive process "the pluralism that it is the business of the courts to protect and the respect for persons that it is the business of the courts to enforce."161

\section{POTENTIAL Is Not PRActice}

If there is any legal field in which the appropriateness of attending to individuals' stories would seem to be obvious, one would think it would be the area of will interpretation. Wills law's notion of a will as the expression of a unique individual's own wishes would seem to commit it to a search for the testator's special, personal circumstances. Yet the doctrines in this area do not encourage the view that a will is a story, and may exclude evidence of the actual story underlying a will's verbal commands. If it is difficult for the law to sanction the telling and hearing of stories in a field whose object is the effectuation of individual wishes, how likely is it that storytelling will achieve its

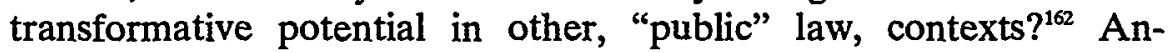
swering this question involves speculation about why will interpretation doctrines seem to stray so far from the ostensible goals of wills law.

One way to begin this speculation is to examine what it is that makes the modernist, meaning-of-words model of will inter-

160. Minow \& Spelman, supra note 137 , at 70.

161. Scheppele, supra note 58 , at 2098.

162. As noted supra text accompanying notes $3-7$, storytelling has been proposed as, among other things, a political strategy by which to empower oppressed groups whose voices and claims have been marginalized by virtue of their position "outside" of the mainstream of American legal culture. I do not mean to argue that the stories of testators and of oppressed groups are necessarily alike. On the other hand, both types of stories are alike resisted. My thought is that if we can understand the resistance to stories in the first category, we might better understand the resistance to stories in the second category. 
pretation seem attractive on any level. As explained earlier, ${ }^{163}$ the meaning-of-words model, based in liberal individualism, requires self-reliance in the use of language. Words can be harnessed to the achievement of the author's ends, and, the model asserts, they should be. In theory, the exclusion of extrinsic evidence unrelated to word use is meant to ensure that, ultimately, words will be so harnessed-if not by this testator, at least by others, who can learn from this testator's failure. ${ }^{164}$

This argument has a certain appeal in the abstract, where whàt matters is what people are theoretically capable of, ${ }^{165}$ not their actual abilities or situation. In this abstract realm, everyone is as competent as everyone else: All will-writers can write plainly; all will-readers can read what has been written; everyone can protect himself against imposition. In this realm of abstractly shared, equal abilities, the moral norm of self-reliance makes a good deal of sense. ${ }^{166}$

Of course, the will interpretation context is not the abstract realm depicted and required by the self-reliance norm. The will's author, being unable to communicate in the present, does not stand on equal footing with the will's reader; the dead and the hiving are not equally powerful. The writing of a will is an act of trust, an "accepted vulnerability" to others. ${ }^{167}$ The prevalence of self-reliance rhetoric in the will interpretation context may function to blind us to these facts. ${ }^{168}$ The doctrinal model frames what is

163. See supra text accompanying notes $85-90$.

164. The standard arguments about using form correctly, of which this argument is but an example, as well as the parallels between such arguments, arguments for self-reliance, and the ideal of individualism, are presented in Duncan Kennedy, Form and Substance in Private Law Adjudication, 89 HARV. L. REV. 1685, 1697-701, 1737-40 (1976).

165. Of course it is questionable whether this sort of self-reliance in language use is possible even as a theoretical matter. See, e.g., FiSH, supra note 105, at 284 ("A sentence is never not in a context. We are never not in a situation .... A set of interpretive assumptions is always in force. A sentence that seems to need no interpretation is already the product of one."); Drucilla Cornell, Convention and Critique, 7 CARDozo L. REV. 679, 689 (1968) ("The very commonness of language renders language essentially independent of an individual's intention to give it meaning").

166. See Annette Baier, Trust and Antitrust, in FEMINISM \& PolmTical THeORY 279, 297 (Cass R. Sunstein ed., 1990) (A conception of morality "as essentially a matter of keeping to the ininimum moral traffic rules, designed to restrict close encounters between autonomous persons to self-chosen ones ... presupposes both an equality of power and a natural separateness froin others.").

167. Id. at 283.

168. See Olsen, supra note 9, at 1529 (The images created by legal rhetoric "limit[] 
actually an imbalance of power and a relationship of trust between differently situated human persons as a compact or contract between equally capable word-users. It thus allows us to avoid the very difficult task of reexamining the self-reliance norm and developing a new norm more appropriate to a relationship of "unavoidable inequality."169

Similarly, the meaning-of-words model presents will interpretation as a problem for which we have fairly well-developed understandings (if not solutions), i.e., a problem of "constraint." In the meaning-of-words model, the testator's meaning (which is not necessarily the same as his "intention") is in the will and must be brought out through some process that keeps it pure of the ideas or preferences of readers. ${ }^{171}$ As with, say, constitutional interpretation, the concern is that the wrong person's unchecked subjectivity-the reader's, the judge's-will control; and the search is for some rule that will rein in that subjectivity. ${ }^{172}$ We may not yet have found the right rule-we still debate the appropriate scope of judicial review in constitutional law and of deference to legislative will in statutory interpretation cases. But the problem is one with which we have grown familiar, even comfortable.

Yet the traditional formulation of the problem of "constraint" only holds up if there is a "correct" subjectivity to which we must defer and an "objective" methodology by which to find it; and in the case of will interpretation, we are taught that the "correct" subjectivity is the testator's. ${ }^{173}$ However, when we abandon tradi-

and impoverish[] the ways we experience our affective and productive lives, the possibilities we can imagine for restructuring our shared existence, and the manner in which we attempt change.").

169. Baier, supra note 166, at 301.

170. See supra text accoinpanying notes 89-90.

171. See Schlag, supra note 91 , at 920 (noting that one "conventional effect of the inside/outside distinction" is that "it essentializes what is on the inside and separates 'it' from what is relegated to the outside") (footnote omitted).

172. Again, the emphasis is on constraint:

[In one model,] social reality consists of social rules ... . Like physical constraints, social and legal rules keep us from doing what we want to do. The idea of constraint evokes the image of a prisoner who must be physically prevented from doing what she chooses to do. If the constraint were absent, the prisoner would spring into action according to her own desires and choices.

Balkin, supra note 82 , at 1140 .

173. In the realm of constitutional interpretation, there is no shared agreement that the Framers' intention(s) must control. There is, however, fairly wide agreement that interpretation must be in some sense "principled" and cannot be based solely on the 
tional modernist notions of liberal individuality, and accept that "our individual reality is socially constructed in and through dialogue with others,"174 it is clear that there is a problem with both halves of this modernist formulation. As a result, the inquiry changes. The question becoines one of the relationship between individual preferences (the "correct" subjectivity) and the social forces that help construct those wishes. In a less modernist vision, "individual preferences... would have already and necessarily been constructed by social forces," including norms never consciously considered by either the writer or the reader of the will. ${ }^{175}$ "Once the social construction of the subject becoines the basic assumption of jurisprudence, one is less concerned with how constraint is possible than with how undesirable forms of blindness can be avoided." 176

Now this problem, the problem of dealing with a partiality that is both inevitable ${ }^{17 \pi}$ and invisible, ${ }^{178}$ is not one with which we are particularly faniliar or comfortable. Justice in our rule of law culture has traditionally been defined in terms of independence, disengageinent, and lack of bias. ${ }^{179}$ If these qualities are unattainable, our conceptions of justice must be changed. ${ }^{180}$ The goal to be sought would not be "objectivity" in interpretation, but consciousness of the multiplicity of ways in which the same event can be perceived, ${ }^{181}$ and open, caring acknowledginent of the

judge's personal political preferences. See, e.g., Mark V. Tushnet, Following the Rules Laid Down: A Critique of Interpretivism and Neutral Principles, 96 HARV. L. REV. 781 (1983).

174. Drucilla L. Comell, Institutionalization of Meaning, Recollective Imagination and the Potential for Transformative Legal Interpretation, 136 U. PA. L. REV. 1135, 1145 (1988); see also supra text accompanying notes 95-96.

175. Balkin, supra note 82 , at 1142 .

176. Id. (footnote omitted).

177. See Minow \& Spelman, supra note 137, at 52 ("[E]ach human being is unavoidably situated in his or her own experience."); Judith A. Resnik, On the Bias: Feminist Reconsiderations of the Aspirations of Our Judges, 61 S. CAL. L. REV. 1877, 1943 ("Impartiality and disengagement can never be achieved, hence all judgment is (sub rosa) suspect, hence we are always living in a second best world in which we cover our tracks with doctrines of insulation.").

178. See Abrams, supra note 6, at 975-76 ("The ostensible 'neutrality' of the law disguises the extent to which it is premised on the perspectives of the powerful ...."); Balkin, supra note 82, at 1148 ("Sometimes racist and sexist attitudes are consciously articulated . . . . However, more often they are unconscious.").

179. Resnik, supra note 177 , at 1882.

180. See Baron, supra note 3, at 104-05.

181. As Professor Scheppele puts it: 
choice of which account will prevail..$^{182}$ These new aspirations are a huge departure from the conventional vision of the goals of interpretation. Indeed, they envision an open embrace of choices that the traditional vision denies can ever properly be made.

A final thread in the tapestry of reasons why wills law embraces the meaning-of-words model of interpretation, and seems so resistant to storytelling, draws on the fact that a signal feature of wills is that they dispose of property. ${ }^{183}$ As has frequently been noted, there is no doubting the association in our legal and social theory between property and modernist, liberal notions of individual autonomy. ${ }^{184}$ That idea of autonomy sees in dispositions of property exercises of "freedom," defined as individually generated, self-controlled choices. ${ }^{185}$

There is nothing foreordained about this view of the self and its choices. ${ }^{186}$ Nor is it always or necessarily helpful to us. Indeed, it may be dysfunctional, for it may wrongly cause us to "doubt anyone's ability to know, or care knowingly, for another," and on this false basis we may "consign ourselves to the impoverished state of disconnection from all except our most intimate companions." 187 Yet whereas psychological disconnection and separation

Stories can be told many ways, and even stories that lead to very different legal conclusions can be different plausible and accurate versions of the same event. It may make sense, then, to think that the presence of these different, competing versions of a story is itself an important feature of the dispute at hand that courts are being called upon to resolve.

Scheppele, supra note 58, at 2097.

182. Wells, supra note 144 , at 1746.

183. But see ATKINSON, supra note 72 , at 2-3 ("[W]hile wills usually dispose of property, this is not necessarily true .... [A] will nay simply appoint a guardian ... or merely revoke former wills.") (footnotes ounitted).

The ideas in this paragraph were first developed in Jane B. Baron, Do We Believe in Generosity?: Reflections on the Relationship Between Gifts and Exchanges, 44 U. FLA. L. REV. (forthcoining 1993).

184. See, e.g., Fellows, supra note 12, at 611 n.1 ("No one disputes the influence of individualisin on the Western concept of property."); Carol M. Rose, Crystals and Mud in Property Law, 40 STAN. L. REV. 577, 605 (1988) ("[I]t seems no coincidence that the doctrimes of fixed promisekeeping and fixed property entitlements developed more or less contemporaneously with a social theory that originally envisioned a radical separateness among human beings.").

185. See Baron, supra note 183.

186. See Pierre Schlag, "Le Hors De Texte, C'est Moi": The Politics of Form and the Domestication of Deconstruction, 11 CARDOZO L. REV. 1631, 1670 (1990) (suggesting that the view of the self as "autonomous, originary, integrated ... [and] self-directive" is the product of ideology).

187. MiNow, supra note 89 , at 227. 
may be the negative sides of the idea of freedom-as-choices, there is another side to this vision-a side that can be seen as positive. Where freedom is defined in terms of individual choices, each individual is relatively free of moral or political responsibility to others. People exercise their freedom by making their own choices, and while they alone must bear the consequences of choices that turn out to be poor, they have no obligation to share the gains resulting from choices that prove to be good. ${ }^{188}$

Recognizing the very different choices we face as individuals constituted by-and not isolated from-society need not undercut our vision of ourselves as free. That recognition requires, however, a different definition of freedom: "To argue that we are immersed in an already constituted form of life does not negate our responsibility to it or our rebellion against it. Our form of life may have an alienating, theatrical quality; but we are still the actors and actresses." $" 189$

This form of freedom is neither familiar nor comforting; indeed, to eyes accustomed to seeing freedom as wholly self-determined choices, it barely looks like freedom at all. "We get queasy when we view the personality of others to be constituted merely by a series of staged performances." ${ }^{190}$ Moreover, the new understanding of freedom that accompanies the vision of a socially constituted self carries with it awesome responsibilities. If the individual is not wholly determined by social forces, ${ }^{191}$ and the rela-

188. See, e.g., id. at 299 (A widely accepted conception of rights relies on the idea that the rights-bearing person is an autonomous individual capable of exercising choice for personal ends.); Kennedy, supra note 164, at 1713 (The self-reliant individualist holds a firm conviction that "I am entitled to enjoy the benefits of my efforts without an obligation to share or sacrifice them to the interests of others.") (footnote omitted).

189. Drucilla Cornell, "Convention" and Critique, 7 CARDozo L. REv. 679, 691 (1986); see also Balkm, supra note 97, at 1848 ("[I]f language is always social, and if freedom consists in activity as a socially constructed individual, then socially constructed and channelled forms of discourse should be seen as empowering rather than inerely confining.").

190. Robert C. Post, On the Popular Image of the Lawyer: Reflections in a Dark Glass, 75 CAL. L. REV. 379, 387 (1987) (footnote omitted).

For a less negative view of the connection between the self and the social roles it plays, see Steven L. Winter, Contingency and Community in Normative Practice, 139 U. PA. L. REV. 963, 986-91 (1991).

191. See Balkin, supra note 82 , at 1137 ("[T] oo great an emphasis on the social construction of the subject leads . . to determinism.").

Some scholars seem to embrace this possibility. See, e.g., Schlag, supra note 92, at 1721 ("Currently, every human contact between selves who are declared, ab initio, to be self-directing and already free is mediated and constructed by techno-bureaucratic strate- 
tion between self and social structure is truly dialectical, ${ }^{192}$ then each individual must be to some degree accountable for our social practices-our law, our culture, our politics. ${ }^{193}$ Liberal visions of freedom may leave us psychologically disconnected, but they impose relatively few moral burdens. The alternative vision emphasizes each individual's connection to and construction by community, ${ }^{194}$ but imposes vague, potentially overwhelming moral responsibilities to create and recreate our selves and our social world all the time.

Of course, if freedom does mean being able to act without responsibility to others, then the freedom that storytelling invites us to embrace is not really freedom at all. Yet even the liberal idea of freedom is not a freedom devoid of responsibility: "Liberalism is the invitation to act in a self-interested manner, without impediment from other people, as long as what we do does not harm them." ${ }^{115}$ Liberals and critics of liberalism have long debated the scope and nature of this limitation, but no one has seriously questioned its existence or importance. If freedom and responsibility are intertwined even in the liberal account, then it does not seem an impossible leap to define our freedom as individuals in terms of responsibilities to others. The point is not, of course, to rescue or reinvigorate liberal notions of freedom, but to recognize that alternative visions-though unfamiliar and untried-are not unthinkable.

To summarize, resistance to storytelling may derive less from the attractiveness of modernist liberalism than from fear of alternatives to it. It is not easy to re-think moral norms, to recognize

gies.").

192. See Balkin, supra note 82, at 1137 ("Individual thought, belief, desire, and action are shaped and constructed by social structures, which in turn are the product of previous individual thought, belief, desire, and action.").

193. See MiNow, supra note 89 , at 309 ("Interpreting rights as features of relationships, contingent upon renegotiations within a community committed to this unode of solving problems, pins law not on some force beyond human control but on human responsibility for the patterns of relationships promoted or hindered by this process."); Willians, supra note 33, at 495 ("The ultimate message of the new epistemology is . . that ethical choices are ours to make, and that we must accept responsibility for the constraints and choices we have embodied in the law.").

194. See Winter, supra note 190, at 991 ("There is . . no separation between the self and its communities. Self and community are mutually constitutive.") (footnote omitted).

195. Joseph W. Singer, The Legal Rights Debate in Analytical Jurisprudence from Bentham to Hohfeld, 1982 WIS. L. REV. 975, 980 (einphasis added). 
the inherent biases of the inost well-intentioned "objective" approaches to decisions, or to re-envision freedoin in terms that are capable of inaking every individual responsible for every other. Inside the ubiquitous and familiar-feeling practices of storytelling lie deep challenges.

The transformative potential of storytelling is, I think, real. Storytelling relies for its intelligibility on individuals' situatedness within culture. Understanding the interdependence of self and culture invites us to re-think the kind of society we wish to make and be made by. Yet nothing ensures that this invitation will be accepted.

Stories may, simply, be difficult to hear. The will story-type can serve as an example. Structurally, the story is about specific people-flesh-and-blood men and women whose least-defining roles, during life, were that of "testator" and "devisee." The story is also, usually, about property-but not property as an abstract concept or institution. Rather, the will often "speaks" of objects (such as wedding rings and rocking chairs) or places (such as homes and farms) that may have been integral to the testator's self-definition ${ }^{196}$ and whose transmission may establish or affirm a relationship to another. The story, whenever written, is heard in the context of death. The rich texture of the story-its emotion and particularity-can help connect us to the person the testator was, ${ }^{197}$ but at the same time renders us specifically and immediately vulnerable to the pain of losing that person. Do we wish to be reminded of our closeness, of the qualities and complexities of our relationships (loving, angry, tumultuous, etc.), at the very moinent of loss?

Nor is it easy to bear the responsibilities that the advocates of storytelling would have us accept. Again, the testator's story can serve as an exainple. The testator has his own unique style of word use, but also-and more important-countless other attributes and characteristics that we think of as forming his personality. To attend to his story, and not merely the words of the will, is in effect to define his identity. ${ }^{198}$.It is probably better to be honest

196. See Margaret J. Radin, Property and Personhood, 34 STAN. L. REv. 957 (1982).

197. Cf. Delgado, supra note 6, at 2438 ("Stories are the oldest, most primordial meeting ground in human experience. Their allure will often provide the most effective uneans of overcoming otherness ....").

198. See Martha Minow, Identities, 3 YAle J.L. \& Human. 97, 127 (1991) ("[A]s people with the power to use language and state authority, lawyers and judges may influ- 
about this fact than to hide behind methodologies that are purportedly neutral but actually distorting. ${ }^{199}$ But how many of us-let alone the legal system-want explicitly to acknowledge this sort of responsibility?

Wills law is ostensibly committed to the effectuation of individual wishes. Few other areas of law share this commitment, even at the rhetorical level. ${ }^{200}$ If we cannot negotiate the obstacles presented by our simultaneous vulnerability to and power over others in the realm of will interpretation, will we do better elsewhere? Just as death makes it difficult to face questions of identity explicitly in the wills context, "difference" may create the same difficulty in other contexts, particularly the "public" law contexts in which, it has been argued, storytelling is most needed. ${ }^{202}$ As Professor Delgado has asserted, stories may "humanize us [and] emphasize our differences in ways that can ultimately bring us closer together." ${ }^{203}$ But as he has also recognized, the more a story varies from the norm either in content or style, the harder it is for "insiders" to hear. ${ }^{204}$ Exactly those qualities that make outsiders "different" may make their stories inaccessible to those who most need to hear them: "The claims of outsiders are often not heard in law because the experiences and reactions and beliefs and values that outsiders bring to the law are not easily processed in the traditional structures of legal narratives."205 The question is not whether stories will be told, but whose story will dominate-and this is a problem of power, not of ignorance. ${ }^{206}$

ence the identities of others and in so doing shape their own identities.") (footnote omitted).

199. See Minow, supra note 137 , at 75 ("Acknowledging partiality may cure the pretense of impartiality .... [W] then have a choice of which partial view to advance or accept.").

200. Contract doctrine comes close. Yet as has frequently been observed, see supra note 24 and accompanying text, the foreseeable reliance of each party on the words of the agreement distinguishes contracts in significant respects from wills.

201. For a penetrating analysis of difference as the product of a comparison with a usually unstated, unperceived norm, see Minow, supra note 137, at 31-57.

202. See, e.g., Delgado, supra note 6; Matsuda, supra note 3; Williams, supra note 3.

203. Delgado, supra note 6 , at 2440.

204. Id. at $2429-31$.

205. Scheppele, supra note 58, at 2097. For examples of this phenomenon, see sources cited supra note 3.

206. See Tom M. Massaro, Empathy, Legal Storytelling, and the Rule of Law: New Words, Old Wounds?, 87 Mich. L. REV. 2099, 2116 (1989) ("Modern American trial procedures do allow trial lawyers to personalize their clients and tell their stories. The di- 


\section{CONCLUSION}

My father and father-in-law have been dead, and therefore silent, for some time now. I sought their stories after they died for the same reason I listened to them speak while they lived: I cared. Confronting their stories has nonetheless been difficult. Particularly in the case of my father's will-a study in both ambiguity and ambivalence-I was tempted to throw up my hands in despair ("I just cannot figure this out."). If it is easy to stop trying to understand even one so close, it is even easier to ignore those who are seen-by virtue of death or of difference-as "other." Storytelling may help us to build bridges, to connect with those others, to care. Ironically, I suspect that the caring must come first. 